\title{
PROCESSES OF GLACIER EROSION ON DIFFERENT SUBSTRATA
}

\author{
By G. S. Boulton \\ (School of Environmental Sciences, University of East Anglia, Norwich NR4 7 TJ, England)*
}

\begin{abstract}
Anstract. Most theories of glacier movement and subglacial erosion have assumed that glaciers rest on rigid bedrock surfaces. Whilst this is probably correct for much of the bed area of most modern glaciers, deformable sediments do occur beneath them and formed a substantial area of the beds of large ice sheets during glacial periods. Observations and theories are presented and reviewed about the processes of glacier erosion of rock and unlithified sediment beds both when they are frozen and unfrozen.

Erosional bedrock landforms, such as roches moutonnées, indicate two principal subglacial erosional processes, plucking and abrasion. Where supraglacially derived debris is unimportant, plucking provides the tools which abrade the bed, and must be a quantitatively more important process than abrasion, though more localized. Where plucking is suppressed, erosion rates must be slow. Subglacial measurements of abrasion rates beneath a temperate glacier are used to test an earlier abrasional theory (Boulton, [ ${ }^{\mathrm{C}} \mathrm{I} 974$ ]). The form of the predicted abrasion-rate curve for changing ice velocity and pressure is verified. This theory successfully simulates two-dimensional erosional bedforms. Subglacial observations demonstrate how flow of basal ice around the flanks of bedrock obstacles causes streaming of debris to occur. It is suggested that this streaming process is primarily responsible for the longitudinally lineated form of large-scale surfaces typical of glacially eroded bedrock.
\end{abstract}

Plucking and abrasion also occur beneath cold ice, though at slow rates, and are probably restricted to places where the ice thickness is small.

Where the glacier bed is composed of unlithified sediment, subglacial measurements show that deformation can produce very large discharges of subglacial material, which makes this a potential agent of very rapid subglacial landform production. The heterogeneity of subglacial sediment leads to spatially variable rates of deformation, and it is suggested that relatively stronger parts of the sediment body may form the nuclei for drumlin and mega-flute formation.

Whereas unlithified unfrozen sediment deforms beneath the glacier rather than being incorporated within it, ice-cemented subglacial sediments can behave like bedrock, because of their relative rigidity, and are readily plucked and incorporated englacially. They may also deform beneath the glacier.

Résumé. Les processus d'érosion glaciaire sur des lits de matériaux différents. La plupart des théories du mouvement des glaciers et de l'érosion sous-glaciaire supposent que les glaciers glissent sur une surface rigide de bedrock. Bien que cela soit probablement vrai pour la plupart des glaciers modernes, une grande partie des Indlandsis du Pléistocène restaient sur une couche de sédiments déformables. Des observations et théories sont présentées concernant des processus d'érosion glaciaire des surfaces de rocher et sédiments nonlapidifiés, lorsqu'clles sont gelées et non-gelées.

Les formes d'érosion telles que "roches moutonnées" indiquent qu'il y a deux processus principaux d'érosion sous-glaciaire, l'abrasion et l'arrachement. Lorsqu'il n'y a pas de matériaux issus de moraines médianes, l'arrachement fournit les outils de l'abrasion, et doit être un processus quantitativement plus important, bien que plus localisé. Lorsque l'arrachement ne se produit plus, les vitesses d'érosion doivent être ralenties. Les mesures des vitesses d'abrasion au-dessous d’un glacier tempéré sont utilisées pour mettre à l'épreuve une précédente théoric de l'abrasion (Boulton, ["I 1974 ]). La forme de la courbe théorique qui relie la vitesse du glacier, la pression à la base du glacier, et la vitesse d'abrasion est vérifiée. $\Lambda$ vec cette théorie, on peut simuler l'évolution de la forme d'une ondulation transierse au sens d'écoulement du glacier créé par l'érosion. Des observations sous-glaciaires montrent comme l'écoulement de la glace basale autour des flancs d'un obstacle produit un sillage de matériaux morainiques. On suggère que ce processus est principalement responsable de la forme allongée longitudinalement qui est typique des reliefs de surface des bedrocks érodés par les glaciers.

L'arrachement et l'abrasion se produisent aussi sous les glaciers froids, bien qu'à des vitesses faibles et sont probablement limités aux endroits où l'épaisseur de la glace est faible.

$\mathrm{Si}$ le lit du glacier est construit de sédiments non-lapidifiés, les mesures sous-glaciaires indiquent que la déformation sous-glaciaire peut produire une très grande vitesse d'érosion. L'hétérogénéité des sédiments sous-glaciaires conduit à des vitesses différentielles de déformation, et on suggère que les parties relativement
dures peuvent former le noyau de la formation des drumlins.

Tandis que les sédiments non-lapidifiés et non-gelés se déforment sous le glacier plutôt qu'ils ne lui sont incorporés, les sédiments gelés peuvent se comporter comme le bedrock, à cause de leur rigidité, et ils sont
souvent arrachés et incorporés par le glacier. * Written while on leave at Mountain Research Station, Institute of Arctic and Alpine Research, University
of Colorado, Boulder, Colorado 80309 , U.S.A. 
Zusammenfassung. Vorgänge der Gletschererosion auf verschiedenem Untergrund. Die meisten Theorien über Gletscherbewegung und subglaziale Erosion nahmen bisher an, dass Gletscher auf festem Felsuntergrund aufliegen. Dies mag wahrscheinlich für einen Grossteil des Untergrundes der meisten heutigen Gletscher zutreffen, es treten aber auch deformierbare Sedimente unter ihnen auf, welche sogar ansehnliche Flächen des Untergrundes grosser Eisdecken während der Glazialstadien bildeten. Beobachtungen und Theorien über die Vorgänge der Gletschererosion sowohl auf Gestein wie auf verfestigten Sedimentschichten, letztere im gefrorenen wie im ungefrorenen Zustand, werden vorgestellt und diskutiert.

Durch Erosion des Untergrundes entstandene Geländeformen, wie zum Beispiel Rundhöcker, lassen auf zwei wesentliche subglaziale Erosionsvorgänge schliessen, nämlich Schürfung und Abrasion. Wo supraglazial entstandener Schutt unwichtig ist, liefert Schürfung die Werkzeuge, mit denen das Gletscherbett ausgeschliffen wird, und muss daher ein mengenmässig bedeutsamerer Vorgang sein als die Abrasion, wenn auch mehr lokal begrenzt. Wird die Schürfung unterdrückt, sind die Erosionsraten niedrig. Es werden subglaziale Messungen von Abrasionsraten unterhalb eines temperierten Gletschers benützt, um eine frühere Abrasionstheorie zu überprüfen (Boulton, [ $\left.{ }^{{ }^{1}}{ }_{1974}\right]$ ). Der Verlauf der vorhergesagten Abrasionsratenkurve in Abhängigkeit von Änderungen der Eisgeschwindigkeit und des Druckes wird bestätigt. Diese Theorie simuliert erfolgreich zweidimensionale Erosionsformen. Subglaziale Beobachtungen zeigen, wie das Fliessen des Grundeises um anstehendes Gestein herum die stromlinienförmige Anordnung von Schutt entstehen lässt. Man darf annehmen, dass dieser Vorgang der stromlinienförmigen Anordnung wohl primär für die longitudinal ausgerichtete Form von grossmasstäbigen Oberflächen verantwortlich ist, welche typisch für Felsuntergrund sind, der Gletschererosion erfahren hat.

Schürfung und Abrasion treten auch unter kaltem Eis auf, jedoch nur sehr langsam; sie sind wahrscheinlich auf Stellen beschränkt, an denen die Eisdicke gering ist.

Wo das Gletscherbett aus unverfestigtem Sediment besteht, ergeben Messungen, dass Deformation grosse Mengen von subglazialem Material freisetzen kann; sie erweist sich damit als wirksames Mittel zur sehr raschen Bildung subglazialer Geländeformen. Die verschiedenartige Zusammensetzung subglazialen sehr raschen Bildung subglazialer Gelandeformen. Die verschiedenartige zus man kann annehmen, dass die relativ stabileren Bestandteile des Sedimentkörpers die Kerne für Drumlin- und "Mega-flute"-Bildung liefern.

Deformiert sich hingegen unverfestigtes, ungefrorenes Sediment unter dem Gletscher eher, als dass es ihm einverleibt wird, so können sich mit Eis verzementierte Sedimente infolge ihrer relativen Starrheit wie angstehendes Gestein verhalten; sie werden leicht herausgeschürft und dem Gletscher einverleibt. Sie können sich aber auch unter dem Gletscher verformen.

\section{INTRODUCTION}

It seems reasonable to suppose that the area of the Earth which is currently glacierized is not significantly different from that of most Quaternary interglacials. During glacial periods, glaciers have been very much more extensive. Thus, most of the areas now occupied by glaciers have probably been continuously covered by ice since at least the beginning of the Quaternary, two million years ago. Glaciers are inevitably agents of net erosion as they transport outwards from their source. Thus, in the core areas of long glacier occupancy, erosion can be expected to dominate over deposition. Direct measurements (Boulton and Vivian, I973; Boulton, [ ${ }^{\mathrm{c}}$ I974]) and indirect assessments (Thorarinsson, 1939; Østrem and Ziegler, 1973) of the rate of glacier erosion suggest that rates of $1 \mathrm{~mm} /$ year are common. Continuous erosion at this rate would cut into the landscape at $\mathrm{I} \mathrm{km} / \mathrm{million}$ years, and thus modern glaciers, which have been in continuous occupancy of their beds throughout much of the Quaternary Period, can be expected, in general, to have bitten down through any soft sedimentary cover into a hard lithified substratum.

It so happens that the majority of studies of the processes of glacier erosion and the erosional landforms which they have produced have been concerned with glaciers resting on

\section{Fig. I. (right) Varieties of glacially sculptured bedrock.}

(a) A group of roches moutonnées in front of Franz Joseph Glacier, New Zealand. Ice movement was from left to right. Note the smoothed stoss and steep lee flanks. The features have a limited longitudinal continuity. This may reflect the inhomogeneity of bedrock or the relatively short time for which abrasion has been at work.

(b) A group of extensive ribs and grooves on Kelleys Island, Lake Erie. Ice flow was away from the photographer. The bedrock is limestone, which commonly carries such relatively continuous glacially eroded features. I suggest that this reflects the relative homogeneity of the limestone and possibly the long time of glacial occupancy at this site. I suggest that the initiation of two ribs reflects the streaming process whereby basal debris-rich ice is deflected around original hummocks, or more resistant zones in the limestone which have since been abraded away. Some of the grooving may have been accentuated by solution. Otherwise, the forms are not untypical of glacially abraded bedrock. (Photographs by courtesy of W. C. Bradley.) 


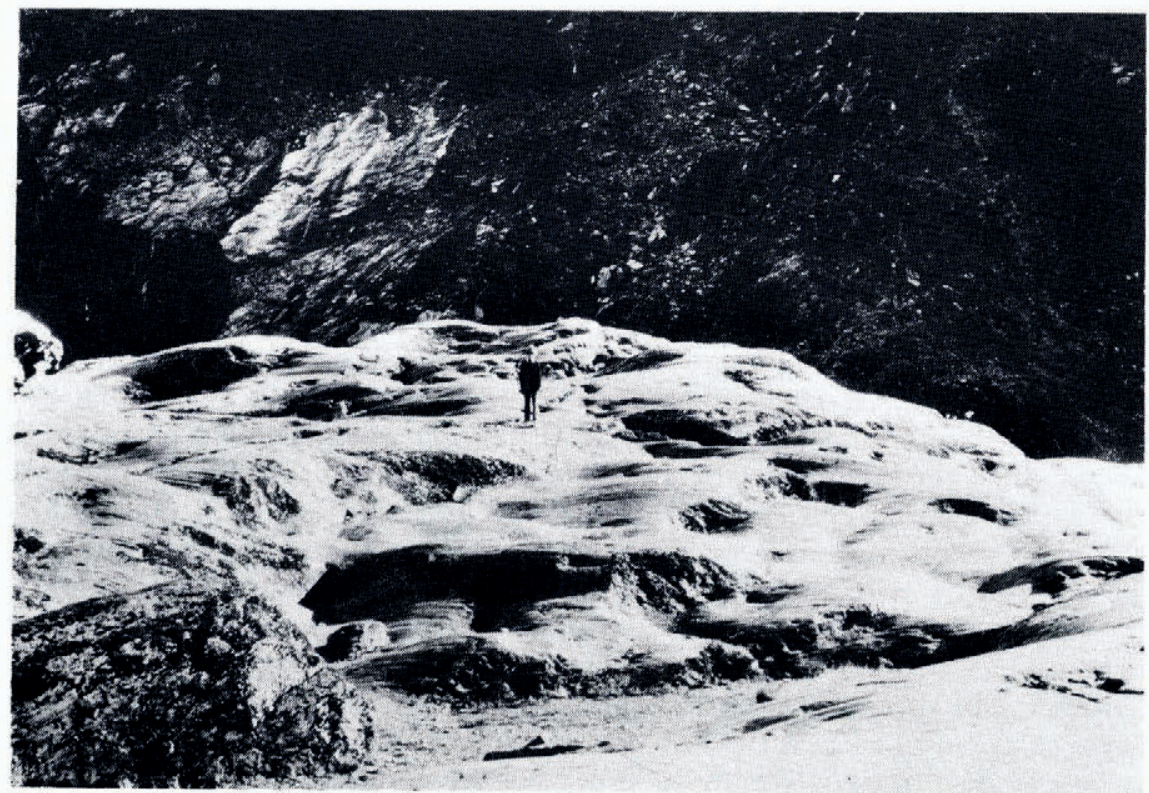

(a)

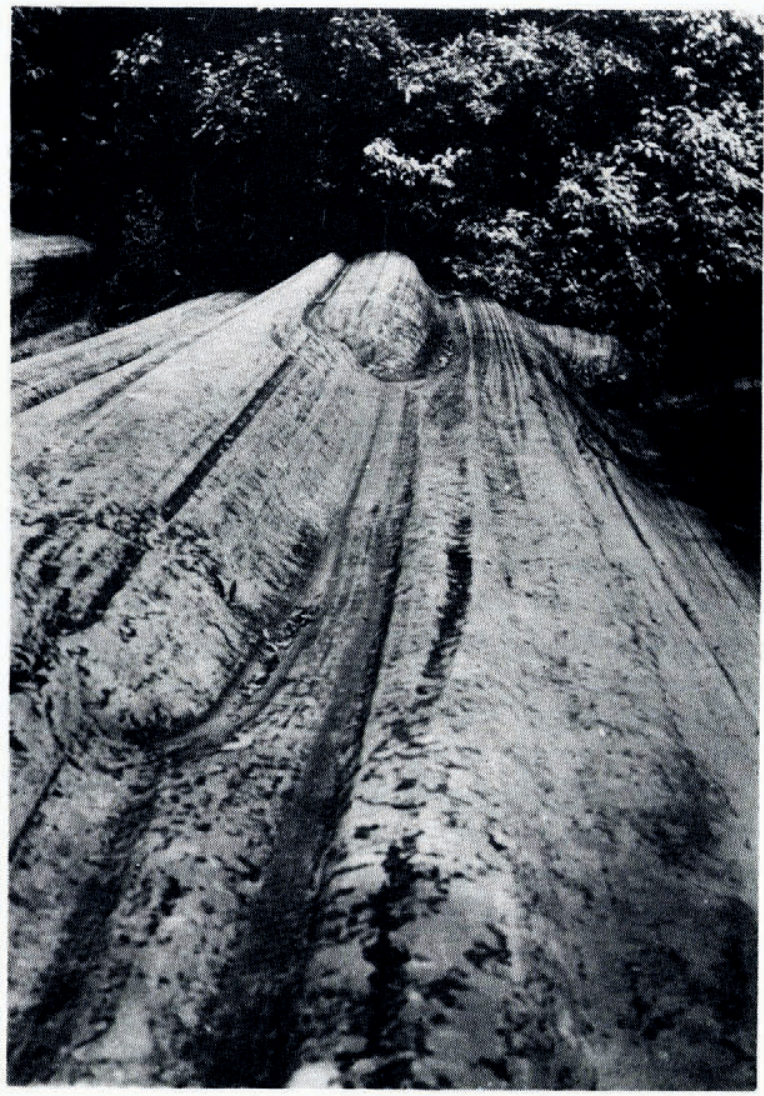

$(b)$ 
lithified bedrock. An implicit assumption of theories of glacier sliding, so necessary in formulating a theory of erosion, has also been that the substratum should be rigid, and for reasons given above, this is probably true for the greatest part of the currently glaciated Earth. However, many glaciers are currently retreating from a "Little Ice Age" maximum during the latter part of the last century in which they over-rode unlithified sediments which had accumulated on bedrock during earlier phases of the present interglacial. In the outer zones of these glaciers, where they rest on unlithified sediment, the existing theories of glacier sliding and glacier erosion, and our concepts of typical glacial erosional landforms do not apply. During the maximum extensions of ice during stadials in the glacial periods, a large percentage of the areas beneath the Laurentide and Fennoscandian ice sheets were composed of unlithified sediment which had accumulated during interstadials and interglacials. Thus, in order to understand the erosional and depositional activity of glaciers over long periods of time and their contribution to the landscape and the sediment record, we need observations and theories not only about glacier movement over rigid bedrock but also over unlithified sediment.

Subglacial processes appear to produce landscapes dominated by streamlined elongated forms whether they are composed of bedrock or deformable sediment (Fig. I), although the forms may vary in detail. The object of this paper is to describe as far as possible subglacial erosional processes which are known to occur, in which the moving glacier sole is the prime agent of erosion, and then to examine if and how these processes erode different types of bed to produce typical landforms. We cannot yet presume that we know all the processes which are important in governing interactions at the glacier/bed interface. More direct observations of subglacial processes are essential in helping us to improve theory.

Two groups of processes which will not be considered are erosion by subglacial streams and removal by valley glaciers of rock debris which has fallen on to their surfaces after being loosened from the valley walls by subaerial processes. Both processes may be locally more important than the erosional processes considered here (e.g. Vivian, 1970; Barsch, 1971) but their contribution to the global flux of glacially eroded material is probably subordinate.

In this paper two principal characteristics will be used as a framework against which to review erosional processes. They are the nature of the glacier bed and the temperature of the glacier/bed interface. I shall contrast bedrock surfaces of high cohesion with surfaces of unlithified sediment in which the cohesion is low and strength is primarily frictional. I suggest that very important differences in processes may occur between such beds.

\section{ERosion of BEDRock SURFACES BENEATH A TEMPERATE GLAGIER}

The majority of opportunities to study processes at the glacier/bed interface have arisen in temperate valley glaciers moving over a rock bed. Thus, most empirical knowledge and theory concerns itself with this condition. The typical forms of glaciated bedrock surfaces are relatively well known. On all scales, transverse roughness is greater than longitudinal roughness. On the small scale, this reflects the presence of grooves and striae cut in the rock surface by boulders embedded in the glacier sole. On an intermediate scale of tens to hundreds of metres, it reflects the presence of longitudinally elongated ridges (roches moutonnées) and grooves for which good explanations are still lacking.

Observations of glacially eroded bedrock surfaces suggest that there are at least two important processes at work: one, an abrading process which smooths surfaces and produces the characteristic longitudinal bedforms, and a second which produces locally "roughened" areas of bed where it has been suggested that bedrock masses have been "plucked" by the glacier (Matthes, i930).

Many believe that plucking exploits pre-existing joints in rocks, and several processes have been suggested whereby entirely joint-bounded blocks may be pulled from the bed and incorporated into the glacier, or where partially joint-bounded blocks may be further fractured 
so that they may then be incorporated. Several processes of fracturing have been suggested: (1) Regelation of melt water in lee-side positions might lead to shattering of bedrock due to ice growth in the interstices (Carol, 1947). However, it seems unlikely that the regelation process can effectively operate on a scale greater than a few centimetres. (2) Glacial unloading may cause dilatation joints in bedrock (Galibert, 1962). (3) Internal stresses induced in a subglacial hummock by glacier flow may lead to fracturing in lee-side positions (Boulton, $\left.\left[{ }^{\mathrm{I}} \mathrm{I} 974\right]\right)$. (4) Boulders in traction in basal ice have been observed to produce fracturing on lee-side crests of hummocks where pressure (and therefore bedrock strengths) are reduced (Boulton, 1978).

There seem to be two processes whereby loosened blocks might be removed by the moving glacier: (1) by the adhesion of the loose blocks to the glacier sole, where the temperature is entirely or locally below the melting point (Lewis, 1940); (2) by plastic flow of ice around loosened blocks (Boulton, [ $\left.{ }^{\circ}{ }^{1974}\right]$ ), although in both cases the blocks must be moved against the frictional resistance of the bed.

The relative importance of abrasion and plucking as erosional agents is difficult to assess. Abrasional tools can have two sources: rocks which fall on to the surface of valley or cirque glaciers in the accumulation area and thereafter travel along basal flow lines, or blocks plucked from the bed (the only source in ice caps and ice sheets). Consider a glacier with no supraglacial debris source, flowing over a bed of constant lithology. In this case, plucked blocks form the only abrasive tools, and they are of the same lithology as the bed. The rate of wear of the tools and the bed is thus likely to be the same, and the rate of lowering of the bed by abrasion must be less than the rate of lowering by plucking, as large blocks survive in the resultant till. The rate of plucking must therefore be an important determinant of the rate of abrasion.

Plucking, though volumetrically important, is a highly localized process concentrated on the distal sides of bedrock hummocks. The streamlined form of glaciated bedrock surfaces is largely a product of more widespread abrasional processes.

\section{Abrasion-observations}

Abrasion is accomplished by rock and mineral debris embedded in the glacier sole and in traction over the bed. There are now many observations of the nature of this basal debris and its motion over the bed (Peterson, 1970; Boulton, [ $\left.{ }^{c}{ }_{1974}\right], 1978$; Boulton and others, 1979; Vivian, 1975). Large clasts in traction are retarded relative to the ice and often have cavities in their lec. Particles of different size and shape move with different velocities. Because of this, particle collisions are frequent and relatively dense particle assemblages frequently build up. Some particles slide, others roll, depending on their shape. Considerable comminution is produced at the interface between large clasts and the bed, which results in production of fine sand and silt rock flour, and may be the single most important global source of silt.

A study of the concentration of particles in basal ice was made in natural cavities and artificial tunnels beneath Breiðamerkurjökull in Iceland. A plan of the volume concentration of debris in the exposed basal ice is shown in Figure $2 \mathrm{c}$. In the centre of cavity $\mathrm{B}$, the concentration in the basal $10 \mathrm{~cm}$ of ice measured from $c .800 \mathrm{~cm}^{3}$ samples was $8-10 \%$ by volume. The thickness of the debris-rich horizon was between 5 and $20 \mathrm{~cm}$. On the eastern side of the cavity, and emanating from a longitudinal trough in the glacier bed, the concentration of debris in similar-sized samples of basal ice was substantially higher, $15^{-20} \%$ by volume. The thickness of the debris-bearing horizon was also greater, being up to $1 \mathrm{~m}$ thick. In an attempt to determine the origin of this higher debris concentration and greater thickness of the basal transport zone, which was also clearly noticeable on the flanks of cavity A, a tunnel was constructed over the up-glacier side of the rock hummock. The directions of the freshest 


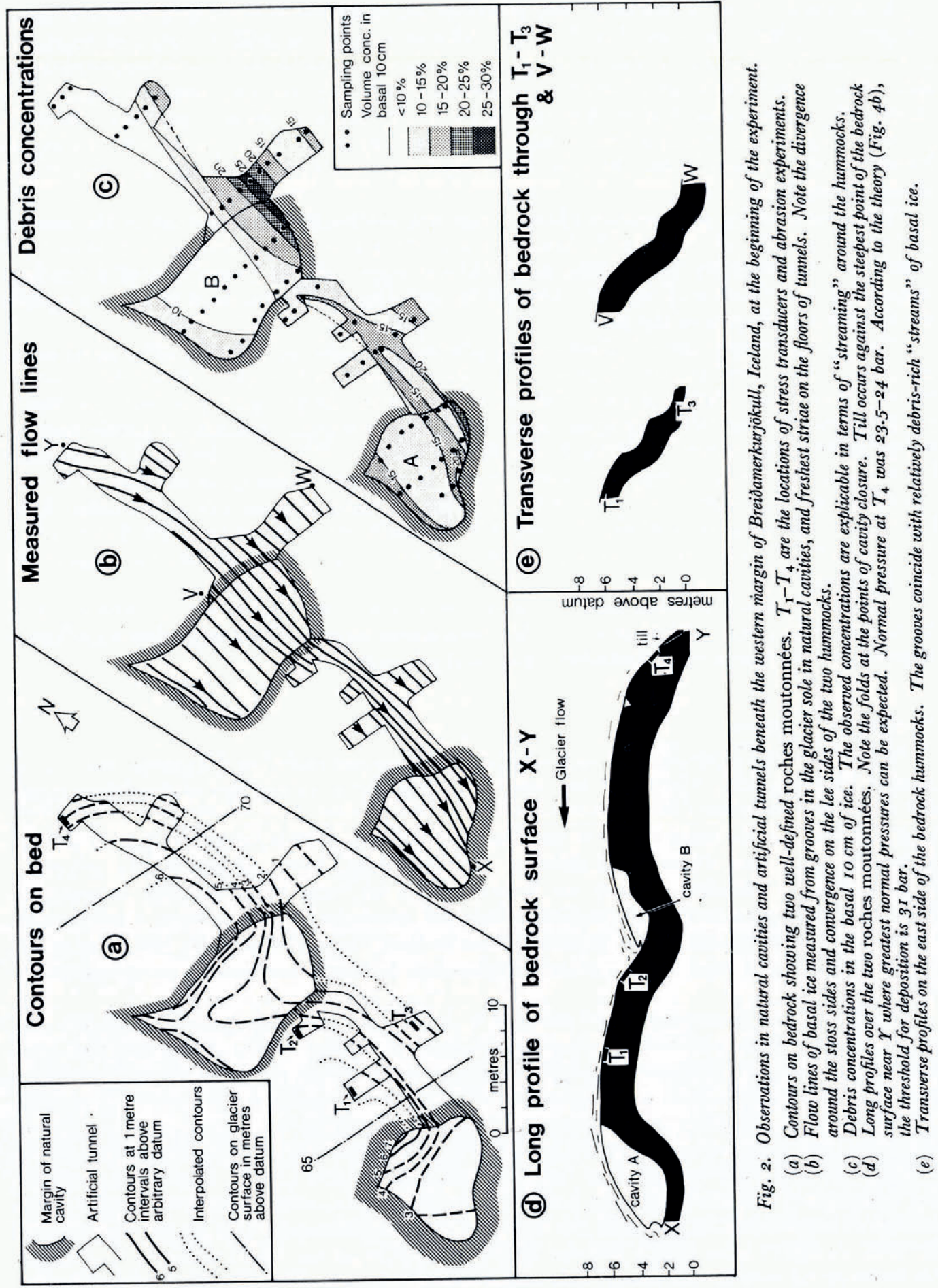


striae, which give an indication of the latest movement of clasts embedded in the glacier sole, were measured on accessible bedrock surfaces (Fig. 2b). This showed a strong flow convergence towards the trough produced by a transverse component of flow around the proximal extremity of the rock hummock up-glacier of cavity B. Such a convergence will clearly be stronger near to the glacier sole and diminish in strength upwards. This will not only tend to thicken the debris-rich horizon in the trough but, as the debris concentration tends to be greatest in the lowest part of the basal transport zone (cf. Boulton and others, I979), and this undergoes greatest lateral flow, the concentration of debris in the trough will also tend to be greater than in the ice moving over the summit of the hummock. Two other important effects are also likely to enhance the debris concentration in the glacier sole in the trough. First, transverse compression and vertical extension will decrease interparticle distances in the plane of the glacier sole. Secondly, net melting at the glacier sole will tend to concentrate debris there, an effect which would be expected to be greatest in troughs because of: (a) a greater geothermal heat flux there (Nobles and Weertman, [ ${ }^{\mathrm{c}}$ I97I]), (b) preferential flow of water in furrows (Weertman, 1972), (c) greater frictional melting due to greater debris concentration in the glacier sole.

I suggest the term "streaming" for the flows which produce concentration of debris-rich ice in low points of the glacier bed, and further suggest that this process is largely responsible for the pattern of debris concentration in basal ice shown in Figure 2c.

On the eastern flanks of both the bedrock hummocks shown in Figure 2 there are major grooves parallel to ice flow and $\mathrm{I}-2 \mathrm{~m}$ in width which can be seen in the cross-sections in Figure 2e. The grooves shown in profile through $T_{1}$ and $T_{3}$ have very sharply defined margins. The concentration of debris in the glacier sole above these grooves is markedly greater than in inter-groove areas. I suggest that this reflects the processes associated with streaming of debris-rich basal ice into the groove. Assuming that normal pressures and velocities are roughly similar in the grooves and inter-groove areas, the higher debris concentration in the grooves should lead to higher abrasion-rates there, thus deepening the grooves, and further enhancing streaming of debris-rich basal ice into them. Presumably, this will continue until "bridging" across the groove decreases pressure in it so as to decrease the abrasion-rate.

\section{A theory of abrasion}

Laboratory experiments investigating the mechanisms of wear along shearing interfaces (e.g. Bowden and Tabor, 1950; Scholz and Engelder, 1976) suggest that a theory of glacial abrasion should be of the form:

$$
A \propto \frac{c \mathcal{N} V_{\mathrm{p}}}{h}
$$

where $\bar{A}$ is the abrasion-rate of the bed, $c$ is the concentration of abrading particles in the ice, $\mathcal{N}$ is the effective normal pressure at the particle/bed contact, $V_{\mathrm{p}}$ is the velocity of the particles and $h$ is the hardness of the bed.

Observations clearly show that particles in traction over the bed are retarded relative to the moving ice. Boulton ([ $\left.{ }^{\mathrm{c}} \mathrm{I} 974\right]$ ) attempted to assess particle velocity in two ways: first, by adapting Weertman's (1957) theory of glacier sliding by replacing fixed cubic obstacles by moving cubic debris particles retarded relative to the basal ice by friction against the glacier bed, and secondly by assuming that rigid debris-rich masses were built up in the basal ice, and using Nye's (1970) sliding theory to determine the relative velocity over its rough upper surface produced by a given frictional resistance of the bed. Using the first approach, the velocity of the particle over the bed was:

$$
V_{\mathrm{p}}=V_{\mathrm{i}}-B l\left(\mu \mathcal{N} A_{\mathrm{i}} / A_{2}\right)^{3}+\frac{C K \mathcal{N} A_{\mathrm{I}}}{L \rho_{\mathrm{i}} A_{2} l}
$$


where $I_{\mathrm{i}}$ is the velocity of basal ice, $B$ a constant in Glen's flow law, $/$ the diameter of the clast, $\mu$ the coefficient of friction between clast and bed, $A_{1}$ the apparent area of contact between clast and bed, $A_{2}$ the area of the clast in the transverse plane, $C$ a coefficient relating pressure and the melting point of ice, $L$ the latent heat of ice, and $K$ the thermal conductivity of ice.

An attempt to test this theory was made at the site beneath Breiðamerkurjökull shown in Figure 2. The techniques employed have been described in previous papers (Boulton, $\left[{ }^{\mathrm{C}}{ }_{1974}\right.$; Boulton and others, 1979). $A_{1}$ and $A_{2}$ (Equation (2)) were measured for different values of $l$ for a basal debris assemblage from Breiðamerkurjökull, for which it is assumed that particle long axes lie parallel to flow, and values of $\mu$ were derived from shear force/normal pressures recorded by the transducer array shown in Figure 2 during the passage of individual clasts. Theoretical values of $\mathrm{V}_{\mathrm{p}}$ were then determined for the whole grain-size range for different values of $、$ (Fig. 3a). Actual velocities of particles of known size and shape can be inferred from their passage over the transducer array shown in Figure 2. The transducer measures eccentricity of load which has a maximum positive value when the centre of gravity of a clast first moves on to the transducer, and a maximum negative value immediately before it leaves.

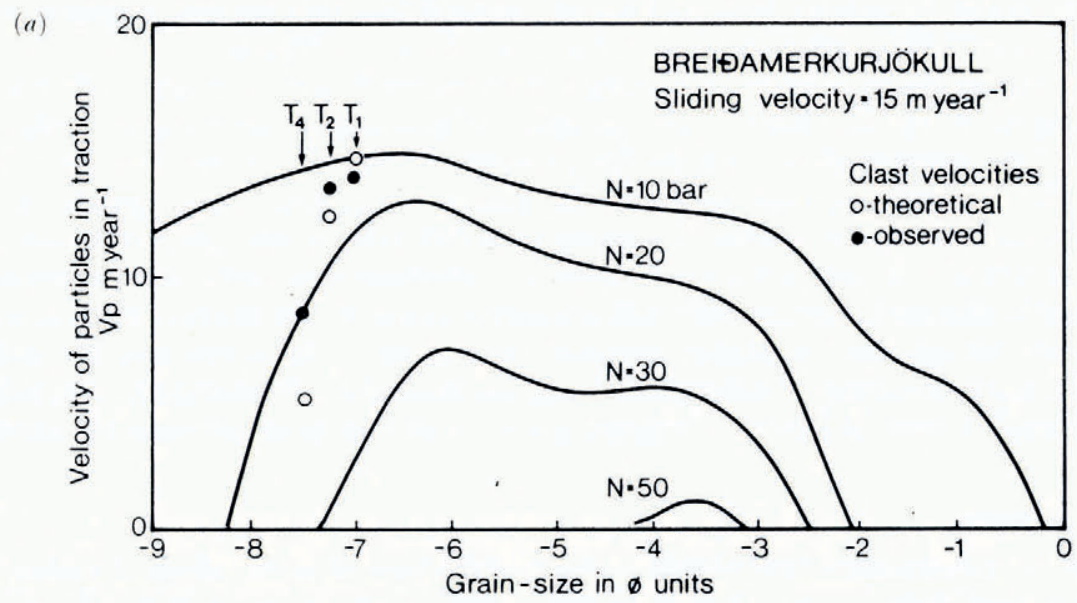

(b)

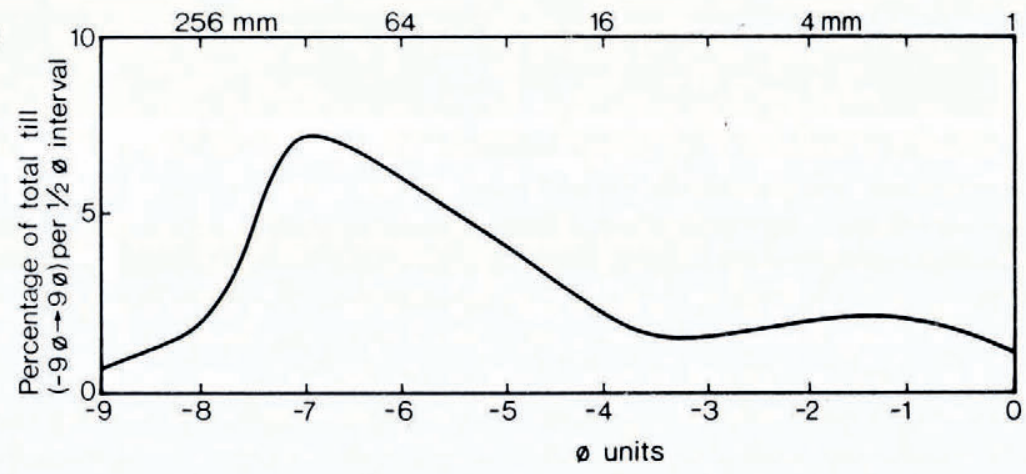

Fig. 3 .

(a) Graphs show theoretical values of particle velocities for different values of effective normal pressure and grain-sizes from $1 \mathrm{~mm}(o \phi)$ to $512 \mathrm{~mm}(-g \phi)$. The irregularities of the curves reflect changing mean values of the shape parameter $A_{1} / A_{2}$ for different grain-sizes. Theoretical and observed values of particle velocities are shown. Mean values of normal pressure at $T_{1}, T_{2}$, and $T_{4}$ are $7.8,16.4$, and 23.5 bar, respectively.

(b) Grain-size distribution for particles between o $\phi$ and $-9 \phi$. 
The time interval between maximum and minimum values allows clast velocity to be estimated. The transducer also gives values of effective pressure on the ice/bed interface (Boulton and others, 1979). These values are plotted in Figure 3 a where they show a similar trend to those predicted by the theory. Velocities at $\mathrm{T}_{2}$ and $\mathrm{T}_{4}$ are underestimated. I suggest three principal reasons for this. First, some clasts may have had cavities in their lee when they moved over the transducer. Secondly, the theory assumes no friction against the sides of the clasts, and thirdly, it is clear that interactions between particles travelling at different velocities are likely to have a strong influence upon individual particle velocities.

The maximum predicted particle velocities occur in the grain-size range $-7 \phi(128 \mathrm{~mm})$ to $-3 \phi(8 \mathrm{~mm})$, which are thus equivalent to Weertman's (1957) controlling obstacles, being the grain-size around which ice has the greatest difficulty flowing. An observed peak in particle velocities occurs between 7.5 and 23.5 bar. Where debris concentrations are relatively large, particle interactions may clearly be very important. The most rapidly moving particles of intermediate size are likely to be slowed down both by larger and smaller particles. Though this effect would act in an opposite sense to the others considered above, it clearly does not entirely counteract them, and velocities are still underestimated.

In order to produce a readily manipulable abrasional theory, it would be useful to derive some estimate of the average velocity of the particle assemblage, or at least that of the coarsest end of the grain-size spectrum which does most abrasional work. In the particular case of the debris in Figure $3 \mathrm{~b}$, I propose to use the velocity of $-7 \phi$ particles as an index of the velocity of the whole debris assemblage, as it is the class that has the largest volumetric representation in the grain-size distribution. Variations in values of $V_{p}$ for this size class for different values of $\mathcal{N}$ and the range of velocities measured beneath Breiðamerkurjökull are shown in Figure $4^{a}$.

If we take $V_{\mathrm{p}(-7 \phi)}$ as a reasonable index of the mean velocity for the whole debris assemblage, then an abrasion-rate can be calculated from Equations (1) and (2):

$$
\bar{A} \propto \frac{c \mathcal{N}}{h}\left[V_{\mathrm{i}}-B l\left(\frac{\mu \mathcal{N} A_{1}}{A_{2}}\right)^{3}+\frac{C K \mathcal{N} A_{1}}{L \rho_{\mathrm{i}} A_{2} l}\right] .
$$

Dimensionless abrasion-rates for measured values of the mean $A_{1} / A_{2}$ at $l=-7 \phi$, and for $V_{\mathrm{i}}={ }_{15} \mathrm{~m}_{\text {year }}{ }^{-1}$ are shown in Figure $4 \mathrm{~b}$.

Net abrasion-rates were measured at a number of points on the bedrock surface shown in Figure 2 by measuring the mean reduction in thickness of rock plates (10 $\mathrm{cm}$ by $5 \mathrm{~cm}$ ) of different hardness after they had been attached, flush with the bedrock surface, for 14 months $(43 \mathrm{I} \mathrm{d})$. Sliding velocities of $14.9 \mathrm{~m} /$ year were directly measured at the beginning of the experiment (April), of I $9.2 \mathrm{~m} /$ year at the end (July), and indirectly by bore-hole and inclinometer surveys in September (13.6 m/year), January (1 1.2 m/year), and April (12.5 m/year). A mean velocity of I $5 \mathrm{~m}$ /year was assumed. Normal pressures at each site were measured by transducers for $4 \mathrm{~d}$ at the beginning and end of the experiment. Mean pressures were smaller at the end of the experiment than at the beginning, presumably because of glacier thinning during retreat. The maximum pressure reduction, of $4.3 \mathrm{bar}$, was measured at $\mathrm{T}_{3}$. Our uncertainty of the precise form of pressure fluctuation for the whole period of the experiment could be a large source of error, although there was nothing unusual about the external behaviour of the glacier, which was frequently monitored during this period. I do not expect large errors to stem from the assumption of a mean pressure value.

At the end of the experiment, the ice which had passed over each transducer during the I4 month period was sampled and debris concentrations measured. These showed little variation, apart from that produced by occasional large boulders.

As might be expected with the relatively crude physical approximations of the theory and the potential errors of measurement, measured rates do not give a good quantitative fit to the theory. However, the measured data are compatible with an extremely important prediction of the theory, that for a constant ice velocity, abrasion-rates will first increase, and then fall 

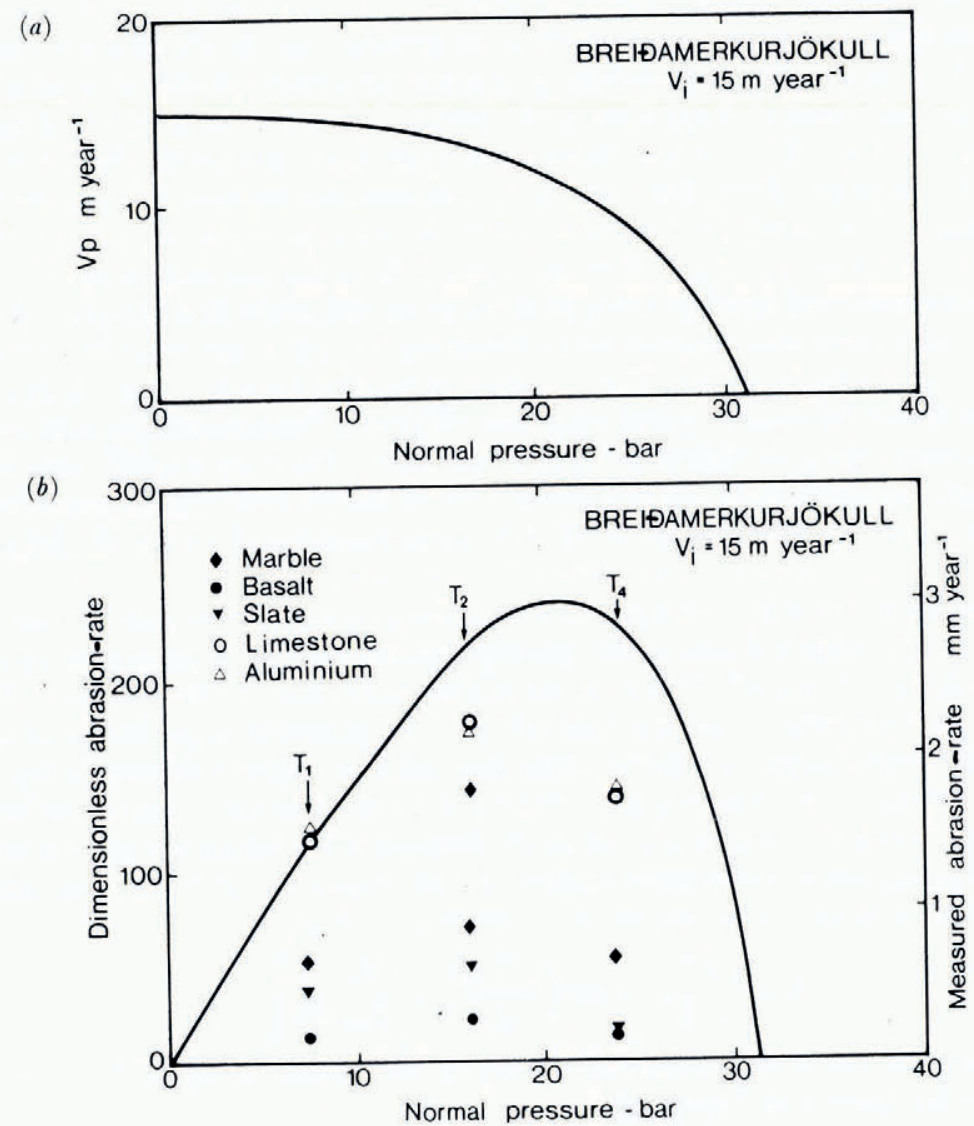

Fig. 4 .

(a) Velocity of $-7 \phi(128 \mathrm{~mm})$ particles of mean shape from Breiðamerkurjökull plotted against effective normal pressure for

(b) A curve showing relative abrasion-rates for changing effective normal pressure and an ice velocity of $15 \mathrm{~m}^{-1}$ year ${ }^{-1}$. Measured abrasion rates for three sites $\left(T_{1}, T_{2}\right.$, and $\left.T_{4}\right)$ and for plates of different material are plotted. The measured abrasion-rate for marble at site $T_{1}$ was plotted on the theoretical curve, and other points normalized. Till had accumulated up-glacier of site $T_{4}$ where the normal pressure was probably somewhat greater than 24 bar. According to the theoretical curve, lodgment should commence at 31 bar. (Measured hardnesses were: aluminium $50-60 \mathrm{~kg} \mathrm{~mm}^{-2}$; limestone $I_{10}-2 I_{5} \mathrm{~kg} \mathrm{~mm}^{-2}$; marble $450-5 \mathrm{Io} \mathrm{kg} \mathrm{mm} \mathrm{mm}^{-2}$; slate $60.5-66 \mathrm{o} \mathrm{kg} \mathrm{mm}-2$; basalt $86.5-905 \mathrm{~kg} \mathrm{~mm}^{-2}$.)

with increasing effective pressure. For this site, predicted values of abrasion-rate peak at 20.9 bar whilst measured values suggest a peak between 7.5 and 23.5 bar, which can probably be more closely estimated as between 16.25 and 23.5 bar.

The theory is not only a theory of abrasion but also a theory of deposition. The two form a continuum in which abrasion occurs when the tractive force of the moving ice is adequate to maintain clasts in motion and deposition occurs when it is not, which in Figure $4 \mathrm{~b}$ is when $V_{\mathrm{p}}=\mathrm{o}$. This suggests that deposition might occur where pressures are very high on the upglacier flanks of roches moutonnées. The prediction is supported by observations beneath the glacier, up-glacier of cavity B, where deposition of till appears to have occurred at a point where normal pressure values were probably somewhat greater than the mean of 23.5 bar measured at transducer $\mathrm{T}_{4}$. This is also supported by observations in the pro-glacial area, where till is frequently plastered against the steepest part of the up-glacier faces of roches moutonnées. 
The rock and metal plates which have been used to determine abrasion-rates have been attached to bedrock in longitudinal series and have therefore undergone a similar erosional history. Abracting clasts are predominantly basalt, and a linear relationship has been found between abrasion-rate and $\mathrm{I} / h$ for plates of limestone, marble and slate. However, this ratio is significantly smaller for basalt plates and relatively variable for granite plates. I suggest that the variability of the abrasion-rate for granite reflects its relative inhomogeneity. It contains large crystals of quartz and feldspar, and some of the wear clearly reflects pulling out of individual crystals. I suggest that the low measured rates for basalt reflect a situation reported in laboratory experiments where asperities whose hardness is less than I.2 times the hardness of the surface (flat) over which they are moving do not plough through it, but that fragments of the asperity adhere to the flat (Bowden and Tabor, 1950; Engelder and Scholz, 1976). However, the interface between a clast in traction and the glacier bed cannot be simply characterized as asperity and flat. Either surface may locally be asperity or flat, and thus clasts and beds of similar lithology probably break down at similar rates. Microscopic studies of the striae left on the experimental plates suggest that ploughing, adhesion, and stick-slip behaviour all occur using the criteria suggested by Engelder and Scholz (1976).

\section{Modelling two-dimensional bedforms}

The abrasional theory embodied in Equation (3) can be used in conjunction with a sliding theory which predicts the pressure distribution over a transverse ridge of low slope for a given constant velocity to predict the way in which the form of the ridge will change with time. This was done by Boulton ([ $\left.\left.{ }^{\mathrm{C}} \mathrm{I} 974\right]\right)$ using a slightly different abrasional theory in which basal debris-rich ice was assumed to behave in a more or less rigid fashion.

However, a two-dimensional bed is rare except where a rock series displaying interbedded units of strong hardness contrasts strikes normal to the direction of glacier flow. Most bedforms also violate the low-slope restriction of existing sliding theories. Nonetheless, this treatment seems to give a reasonable qualitative approximation to the longitudinal profiles of many

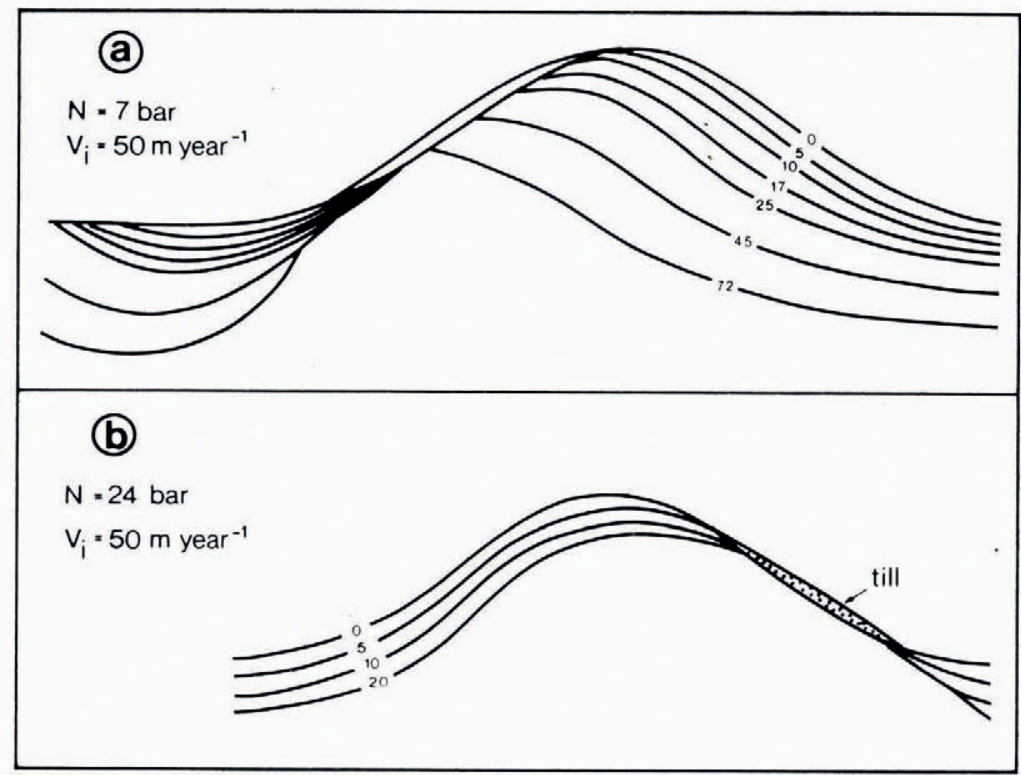

Fig. $5 a$ and $b$. Modelling the evolution of two-dimensional abrasional bedforms, showing the influence of different ranges of normal pressure on the resultant forms. Numbers of computational steps in each form are shown. 
glaciated hummocks and ridges (Fig. 5). The normal-pressure distribution over the sinusoidal cross-profile of a ridge elongated transverse to flow was computed for a constant ice velocity parallel to its surface using Nye's (1 970) sliding theory. This was done for two values of iceoverburden pressure which were selected so that the range of pressure over the ridge lies (a) entirely to left of the peak in the abrasion-rate curve (Fig. 4 b), (b) entirely to the right of the peak. The lowering of the surface by abrasion was then computed. The pressure distribution over the new bedform was then re-computed and the process repeated. By a series of such steps the progressive evolution of the form of the bed was followed (Boulton, [ ${ }^{\mathrm{c}}$ i 974$]$ ).

In case (a), maximum abrasion-rates are initially concentrated at the steepest point of the up-glacier slope and at the foot of the down-glacier slope. Because of this, and the existence of a cavity on the down-glacier flank, the form becomes asymmetric but is finally reduced to a step with a basin on its down-glacier side. This is a particularly interesting prediction in view of Lewis's (1947) demonstration of a continuous gradation from roches moutonnées to valley steps. In case (b), maximum abrasion-rates are concentrated on the down-glacier side and deposition rather than abrasion occurs on the up-glacier side. The form becomes asymmetric but in the opposite sense to case (a). In case (a), the form develops down-glacier asymmetry, like a classical roche moutonnée, and its summit migrates in the same direction. In case (b), the form develops up-glacier asymmetry, like a classical drumlin, and its summit moves in that direction. In case (b), it is possible that a considerable accumulation of till on the up-glacier flank might change its shape considerably. In case (a), till might be expected to accumulate in the cavity.

It is unlikely that subglacial conditions will ever remain sufficiently stable to allow these two trends to be perfectly followed. However, it is reassuring that the theory can simulate three common subglacial bedforms: roches moutonnées with a down-glacier asymmetry, steps with depressions in their lee, and drumlin-like forms.

\section{Evolution of a three-dimensional rock bed}

Glaciated bedrock surfaces are normally strongly ribbed, furrowed, and streamlined parallel to the direction of glacier movement (Fig. I). How does a glacier achieve this when it moves over an area of hitherto unstreamlined bedrock? Consider a surface on which there are a series of randomly distributed bedrock hummocks and over which the glacier flows at roughly constant velocity. Differential abrasion of the surface will occur because of changes in normal pressure, ice velocity, and debris concentration. Unfortunately, there is as yet no theory which allows us to estimate pressure and velocity changes around a three-dimensional hummock, and thus I shall develop a qualitative argument about the role of changing debris concentration.

It has been suggested that the flow of basal ice around hummocks tends to concentrate debris-rich ice around the flanks (Fig. 2). Both debris-rich flanking ice and debris-depleted over-riding ice flow into the lee position, but it is clear that there will be residual lateral contrasts in debris concentration producing a net "streaming" (Boulton, [ ${ }^{\circ}{ }_{1974}$ ). In effect, the bedrock hummocks produce a shadow zone in which the debris concentration is lowered and abrasion-rate is reduced. This streaming effect will clearly tend to enhance relief by a positive feedback in which the cutting of grooves due to the greater abrasion-rates produced by debris streams concentrates even more debris, and I suggest that it may be the prime agent at work in producing large-scale lineations on bedrock surfaces. If there is a strong lateral flow of flanking ice into the lee position, then the streaming effect will be minimized and shorter, elongated bedforms will be produced. If the lee position is primarily filled by over-riding ice, the streaming effect will be greatest and bedforms will be relatively elongated. I would expect high pressures and low velocities to favour the first case and low pressures and high velocities to favour the second. 
Just as original topographic irregularities can lead to streaming and the progressive development of a well-lineated surface, areas of harder rock can play precisely the same role. Limestone is frequently found to develop regular ridges and grooves of great longitudinal extent (e.g, Fig. Ia). I suggest that this might occur because of the tendency for many limestones to be very homogeneous. However, infrequent hard nuclei, such as cherts or silicified fossils, abrade less rapidly, and thus form upstanding knobs which produce streaming. The homogeneity of the limestones then allows long ridges and troughs to develop, whilst the original nuclei may be abraded away, though leaving the inherited knob which is the source of the streaming. Less homogeneous rocks produce elongated features which lack great continuity (Fig. Ib).

(a)

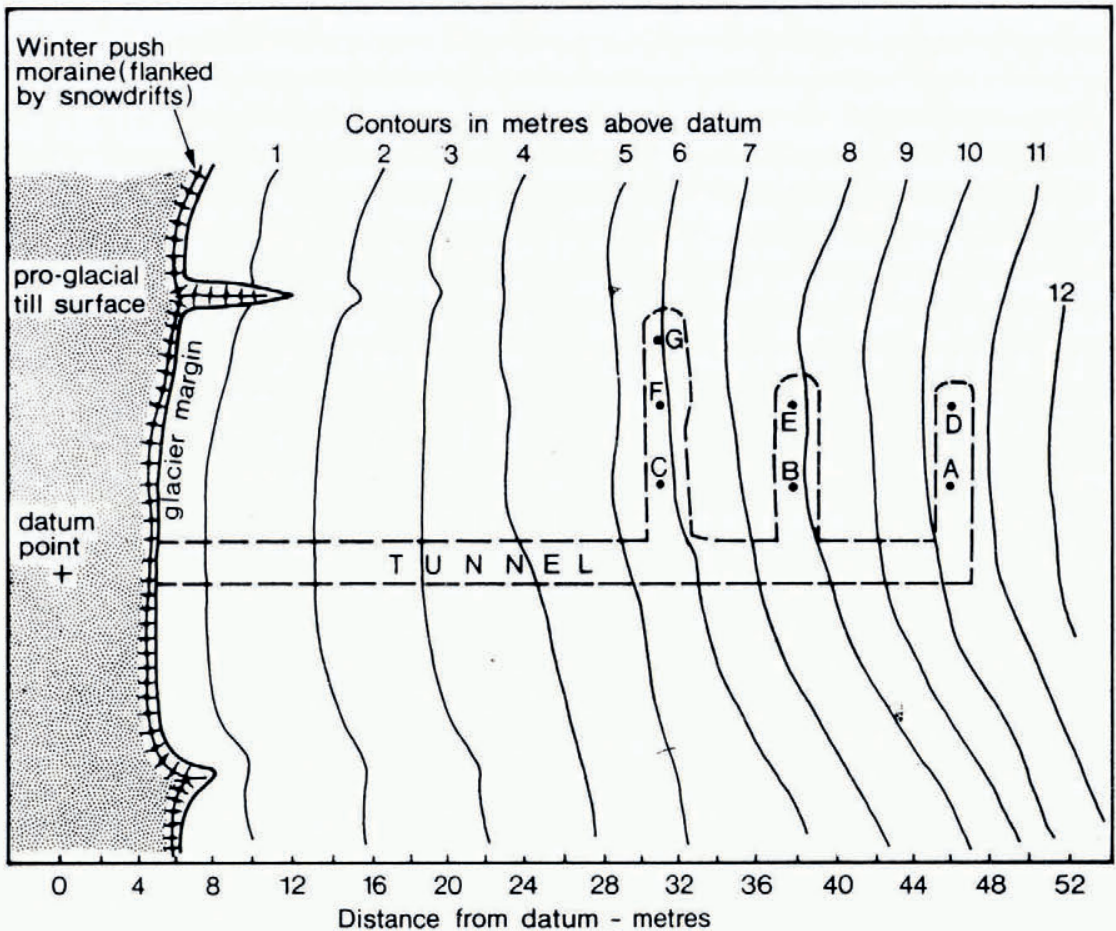

(b)

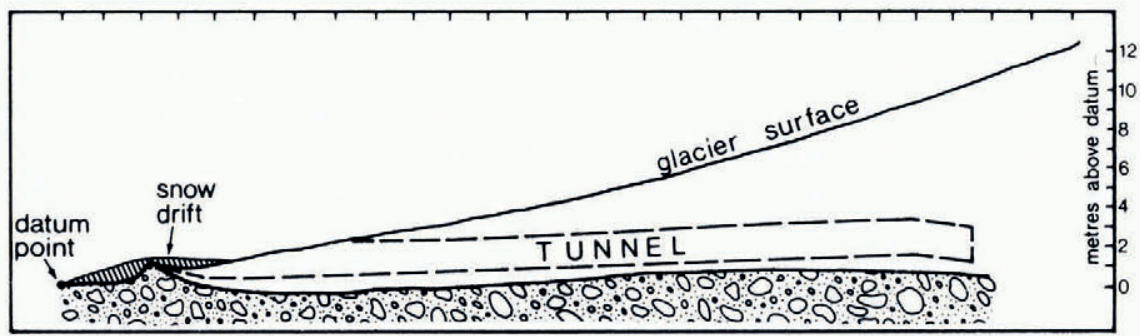

Fig. 6.

(a) Map of part of the western ice margin of Breidamerkurjökull, showing a plan of the tunnels and the positions of successful subglacial probes $(A-G)$.

(b) Section along the line of the principal tunnel and the profile of the glacier/till interface established by probes. The tunnel floor lies $1-2 m$ above the glacier sole. 


\section{EROSION OF BEDROCK BENEATH A GOLD GLAGIER}

There are few observations which throw light on erosional activity at cold glacier/bedrock interfaces, though there is much speculation.

Goldthwait (196o) showed that boulders over-ridden by the cold margin of the ice sheet of north-west Greenland near Thule had not been deprived of their covering of lichen. This appeared to bear out a theoretical expectation (Jellinek, 1959) that the adhesive strength of a cold ice-rock interface should be much greater than the shear stress at the base of a glacier, and thus that there should be no slip on this interface. However, Boulton (1972) suggested that differential movement would occur along a smooth flow line approximating to the shape of the bed. This would be the lowest level at which debris could be transported, and which would only come into contact with the bed and erode it at the summits of protuberances. Holdsworth's (1974) observations in a tunnel beneath Meserve Glacier in Wright Valley, Antarctica, provided support for this concept. He observed an "effective bed" forming a smooth curve above a bouldery surface and which, when it impinged against the summits of subglacial boulders, allowed debris in transport to abrade the boulder summits. However, this is clearly not a very effective current process of erosion at this site, and the fact that the glacier, after a probable occupancy of at least I million years, has not eroded a significant channel for itself suggests that subglacial erosion has also been slow in the past.

Must we then necessarily assume that cold glaciers accomplish very little erosion of bedrock, or are there other local conditions which might produce higher erosion-rates? I would suggest that, if a high discharge-rate of large clasts were maintained over a bed such as that described by Holdsworth, significant abrasion of that bed would occur, and that the bed would be successively trimmed down until it approximated a series of smooth slip lines as envisaged by Nye and Martin (1968), provided that glacier flow remained steady. Such debris clasts could be derived from material falling on to the surface of a valley glacier, from an up-glacier temperate zone, or from plucking of the bed.

The adhesion of basal ice to bedrock would favour plucking in places where the "effective bed" in Holdsworth's sense is tangential to the bedrock surface, which will tend to be on the summits of protuberances. This is the position in which the detachment of already loosened blocks is most likely to occur because of reduced frictional resistance to displacement where pressures are small and especially where lee-side cavities occur. This will always be in the marginal zone of the glacier, as there will be no water pressure acting to reduce effective pressures under great ice loads.

Thus, I would suggest that limited erosion of bedrock is likely beneath cold glaciers, but that it will be restricted to marginal areas.

\section{ERosion of UNLITHIFIED MATERIAL BENEATH A TEMPERATE GLAGIER}

\section{Processes}

On the basis of the characteristics of some of the lodgement tills progressively exposed beyond the retreating margin of Breiðamerkurjökull in Iceland, it was suggested (Boulton and others, 1974) that the upper part of the till underwent continuous deformation beneath the glacier. Several experiments were undertaken to establish if this indeed occurred. An experiment which finally produced unequivocal evidence of subglacial deformation was undertaken during $1977-78$. A tunnel system was dug in the ice about $\mathrm{I}-2 \mathrm{~m}$ above the glacier sole (Fig. 6) and probes were inserted into the underlying till at several points. The probes consisted of a series of contiguous annuli which fitted around a central rod and which could be detached by a counter-clockwise turn. The probe was inserted to depths varying from 0.6 to $0.85 \mathrm{~m}$ where boulders in the till allowed it, and the central rod was withdrawn. The narrow access holes were then sealed off using wooden plugs. After a period of ro d the till was 
partially drained by pumping. The annuli were carefully excavated and their positions plotted. Water pressures had been measured by piezometer at each site during the experiment, and the form of the glacier/bed interface plotted using probes. The full experiment will be described elsewhere.

Figure 7 shows the results at one site. About $90 \%$ of the total basal movement of the glacier is contributed by deformation of the bed materials and only 10 $\%$ by slip between the glacier sole and till surface.

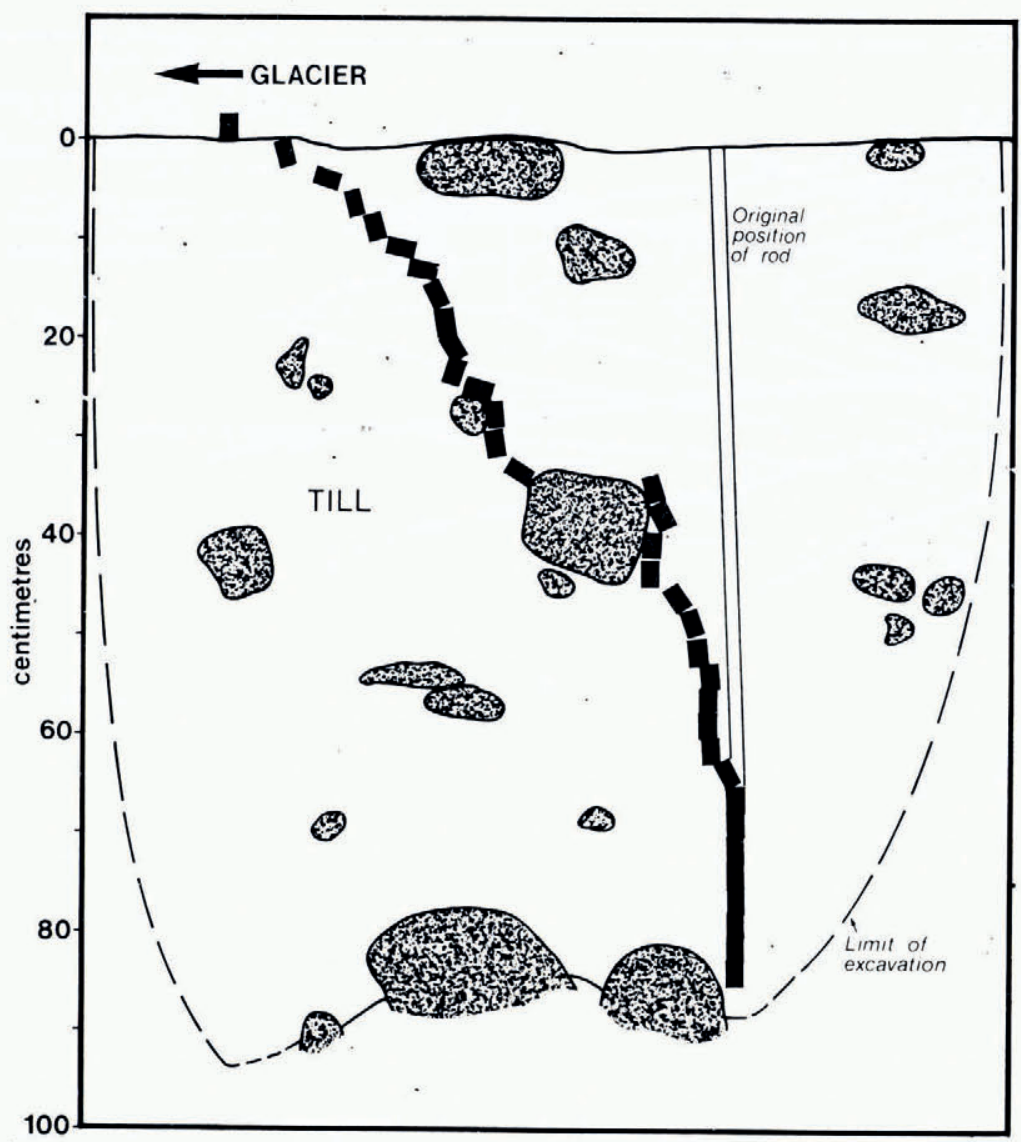

Fig. 7. The position of individual annuli at locality $A, 244 \mathrm{~h}$ after their original emplacement in the position shown. $90 \%$ of the forward movement of the glacier sole is accounted for by deformation of the till. Boulders clearly strongly influence the pattern of deformation. The discharge of till at this site is $1122 \mathrm{~cm}^{3} / \mathrm{cm}$ in $244 \mathrm{~h}$.

It was possible to measure not only the net discharge of till at each site beneath the glacier but also the mean direction of movement of the till mass. It was found that a constant till discharge was not maintained along a glacier flow line. If we assume that the till is relatively incompressible on such small time scales, we must conclude either that there are locally strong vertical movements of the ice/till interface, which is not generally supported by repeated surveys of the ice/till interface (determined by probing), or that a lateral component of till flow occurs. This latter explanation is supported by measurements of the net movement direction of till which is not necessarily parallel to the direction of movement of the glacier 
sole and flutes at the glacier/till interface. Figure 8 gives a simple explanation of the observed rates of discharge per unit width, and flow directions, assuming an incompressible till and a stable glacier/till interface. It is interesting to note that the zone of converging flow is a relatively low area and the zones of diverging flow are relatively higher areas. The surface immediately beyond the glacier margin consists of low-relief drumlins with flutes on their surfaces. It seems likely that the subglacial forms determined by probing are parts of two drumlins separated by a broad furrow.

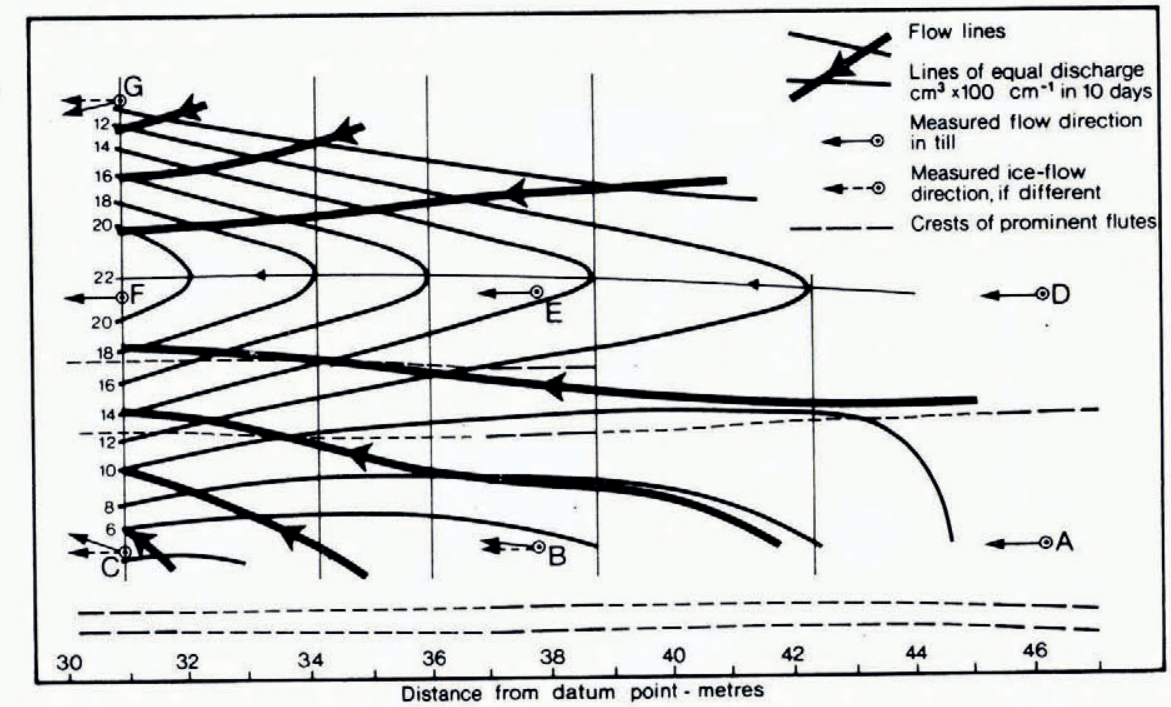

Fig. 8. Plan position of localities $(A-G)$ at which subglacial deformation of till was measured. The measured directions of discharge and the direction of movement of the glacier sole are shown. The simplest contouring of lines of equal discharge per unit length has been produced. The flow lines required to produce this pattern of discharge have been determined, assuming a constant thickness of the deforming layer, an incompressible till, and no vertical movement of the glacier/till interface. The zone of converging fow is a broad furrow between two ridges which are co-axial with muted drumlins in the pro-glacial area, and which pass under the glacier margin. It is important to note that flow of till occurs across the axes of flutes, which are parallel to the measured direction of motement of the glacier sole.

At several sites now exposed beyond the margin of Breiðamerkurjökull there are stratified sediments which have been folded subglacially, presumably by the processes described above. The folds have flat-lying axial planes with synclinal axes pointing up-glacier and highly attenuated anticlinal fold closures. It has sometimes been presumed that deformation of an unfrozen stratified sediment beneath a glacier would lead to destruction of that stratification. This does not happen, either for frozen or unfrozen sediments. Indeed, it is difficult to see how the independent particle motions required to destroy stratification could be achieved.

\section{Implications for glacial erosion and landform development}

If the process described here is widespread, it is a very powerful process of glacial transport and potentially able to accomplish extremely rapid geomorphic results. The rate at which mineral material is discharged by this process is at least ten times faster than the rate of discharge of debris in the basal ice and 200 times faster than debris discharge in the medial moraines of Breiðamerkurjökull. 
The internal frictional and cohesive resistance to movement in the till is overcome by the shear force generated by movement of the glacier. The shear strength of the till can be described by a simple Coulomb law:

$$
S=C+\left(P-P_{\mathbf{w}}\right) \tan \phi
$$

where $C$ is the till's cohesion, $\phi$ its angle of internal friction, $P$ the ice pressure, and $P_{\mathrm{w}}$ the water pressure. At the site shown in Figure 7 , the internal frictional resistance of the till $\left(\left(P-P_{\mathrm{w}}\right) \tan \phi\right)$ is low. However, it has been determined experimentally (Boulton and others, 1974) that near the snout $\left(P-P_{\mathrm{w}}\right)$ increases in an up-glacier direction, and a theoretical analysis (Boulton and others, 1974) suggests that this increase is maintained towards the glacier source. Thus the strength of the till can be expected to increase progressively in an up-glacier direction and at some point the drag force imposed by the moving glacier will be insufficient to cause deformation of the bed. If the glacier front were to remain stationary, the effect of this process would be to create a sub-marginal depression parallel to the ice front. If retreat of the glacier were irregular, depressions would develop where glacier retreat was relatively slow. Breiðamerkurjökull has retreated about $4 \mathrm{~km}$ during the last go years, and from time to time the retreat rate has been relatively slow. During such periods, push moraines are formed, and behind groups of such moraines it is common to find broad depressions. This phenomenon has been widely identified in areas of Quaternary glaciation (e.g. Jelgersma and Breeuwer, 1975).

It is difficult to avoid the conclusion at Breiðamerkurjökull that the drumlinoid surface beyond the glacier must be related to the powerful transporting processes which occur beneath it. Indeed, the movement of material beneath the glacier seems to be geometrically related to the subglacial continuations of pro-glacial drumlins (Fig. 8). The till at Breiðamerkurjökull contains a large proportion of coarse particles, many up to $\mathrm{I}-2 \mathrm{~m}$ in diameter. Observations at the surface show that these are not randomly dispersed but tend to be clustered (Boulton and Paul, I976). If such a material deforms beneath the glacier, the coarser parts will tend to deform less rapidly than other parts, will block movement of material on their up-glacier sides, and thus produce transverse flow components, and provide a shadow-zone in their lee in which material will be relatively protected from deformation. Thus they will tend to generate long streamlined drumlins. If we presume the original inhomogeneities to have been randomly distributed, drumlins will tend to show an average spacing dependent upon the number of drumlin nuclei per unit area, and may coalesce. The drumlins will represent areas of net accumulation and the inter-drumlin zones areas of net erosion. Irregularities on the sub-sediment bedrock surface may play precisely the same role in blocking deformation and nucleating drumlins as inhomogeneities in the deforming sediment.

This process is potentially a very powerful agent of geomorphic work. It might occur deep beneath a glacier where high water pressures produce relatively small effective pressures $\left(P-P_{w}\right)$ and thus low sediment strength. But it will always tend to operate in the marginal zone of temperate glaciers, and thus pre-existing drumlins formed deep beneath the glacier surface will tend to be substantially and rapidly modified beneath the glacier margin, and their final form will reflect conditions there. It is common to find drumlins emerging from beneath the retreating margins of modern glaciers, and in my experience they invariably reflect the direction of flow in the marginal area, testifying to the rapidity of modification in that zone.

I do not suggest that the process of drumlin formation proposed here is the only drumlinforming process, but I do suggest that it is potentially the most powerful. It is similar to the process proposed by Smalley and Unwin (1968) in the respect that it requires deformation of the glacier substratum, but it does not require that the substratum be dilatant as they suggested. 
Shaw and Freschauf (1973) (also Shaw (1975) and Aario (1977)) have proposed another mechanism for drumlin formation whereby helical flows are set up in the ice, which cause thick debris-rich ice zones to build up above the zones of flow convergence, which on melting out produce drumlins. The process proposed here sees the role of glacier and bed quite differently. The bed is soft compared with the glacier, and therefore deforms more readily. The bed is also less homogeneous than the glacier and thus differential deformation and lateral flow take place more readily in the bed, leading to the production of streamlined landforms on the shearing interface.

Drumlins and mega-flutes exposed beyond the retreating margins of modern glaciers invariably have flutes on their surfaces, which show little deflection when followed over those surfaces. The flutes, which were formed in grooves in the glacier sole, must reflect flow lines on the glacier sole. The observations at Breiðamerkurjökull show that lateral flow of till across the trend of flutes can occur, and therefore across the flow lines in the glacier sole. It is difficult to see how the helicoid flow process could have drumlin-producing cells which cross the glacier flow lines marked by flutes.

The threshold for deformation and the rate of deformation of fine-grained sediments (e.g. Roscoe, 1952) are very sensitively dependent on pore-water pressures or small changes in grain-size distribution and mineralogy. The precise sequence of beds along a flow line beneath the glacier plays an important role in governing pore-water pressures (Boulton and Paul, I 976 ). Thus, if that sequence is changed by an advance or retreat of the glacier margin, porewater pressure can change dramatically. Changes in pore-water pressure can also be produced by addition or loss of surface water to the subglacial aquifer. Increases in mass balance, which increase the basal shear stress, may also cause hitherto stable sediments to deform or deforming sediments to flow more rapidly. Thus the dynamic equilibrium of glaciers resting on beds of fine-grained sediment may be very unstable, and surging behaviour might result. A possible example of a glacier surge caused by a deformable water-soaked subglacial bed has recently been documented by Mokievsky-Zubok (1978).

\section{ERosion OF ICE-CEMENTEd SEDIMENTS BENEATH A COLD GLAGIER}

\section{Direct observations}

Wright Lower Glacier in Wright Valley, Victoria Land, Antarctica, has over-ridden a series of wind-blown sand dunes. The glacier margin, like many in this area, is vertical, and along the northern frontal and lateral margins the contact between the glacier sole and the underlying sediments is clearly exposed. The sediments comprise fine- to coarse-grained well-bedded sands. In places where they are relatively undisturbed, small-scale cross-bedding and rippled bedding can be found. Active dunes beyond the margin of the glacier give some indication of the state of the sands before they were over-ridden. The dune sands are cemented by ice, and the voids generally have a high saturation of above $70-80 \%$, though some strata have as little as $20 \%$ void saturation. There are also many ice layers interbedded in the sands. The dunes originally formed from a mixture of blown sand and blown snow, and the ice in them represents metamorphosed snow. The varying ice concentration reflects the varying contribution of snow to the dunes, though sand predominates, partially because of the low annual precipitation of snow $\left(c .6 \mathrm{~g} \mathrm{~cm}^{-2}\right.$ year $\left.^{-1}\right)$ and partly because of sublimation of snow and ice. On inactive surfaces there is normally a layer of ice- and snow-free sand, which I presume to reflect loss of snow and ice due to sublimation in the very dry atmosphere.

The glacier/sand interface is relatively smooth with occasional hummocks $\mathrm{I}-3 \mathrm{~m}$ above adjacent troughs. Several of these clearly represent original dunes. The frozen sand is heavily fractured in places, especially near the crests of hummocks, and sub-surface voids are common (Fig. 9a). In places, angular discordance of bedding across joint planes indicates that block rotation has occurred (Fig. ga). Some of the interbedded ice strata have in places flowed along 


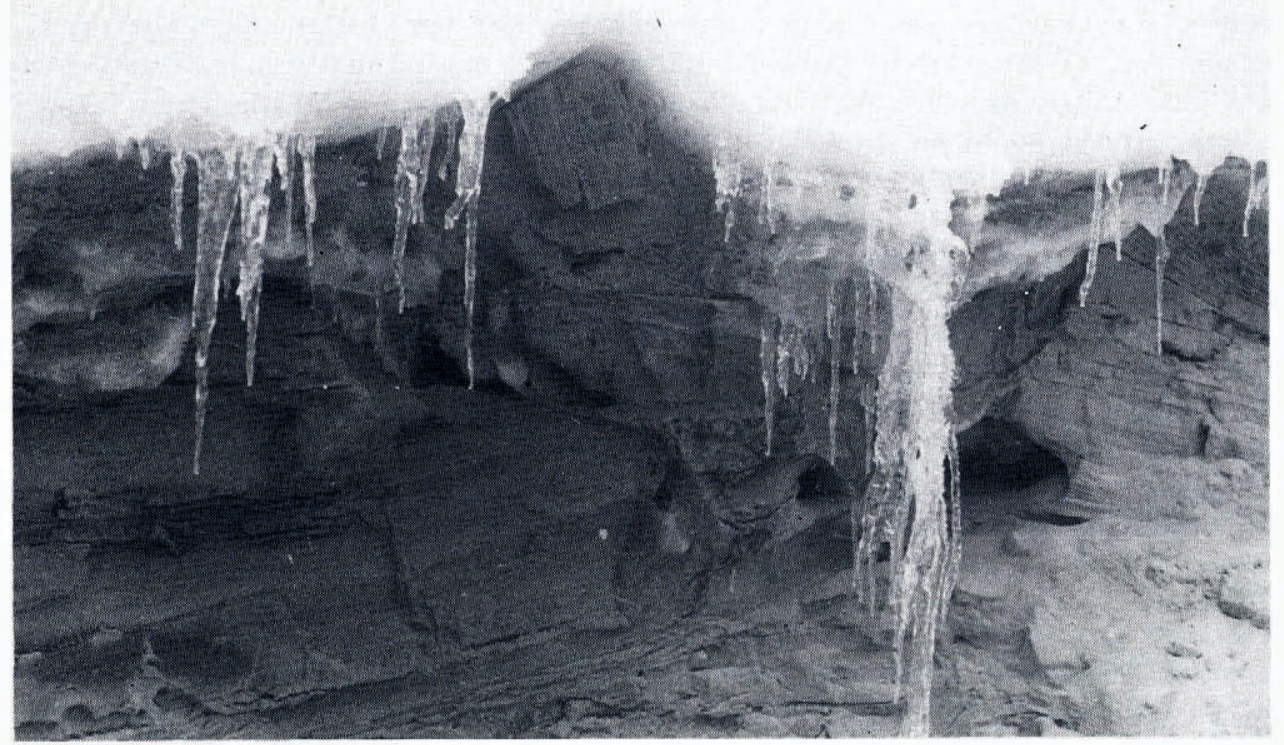

(a)

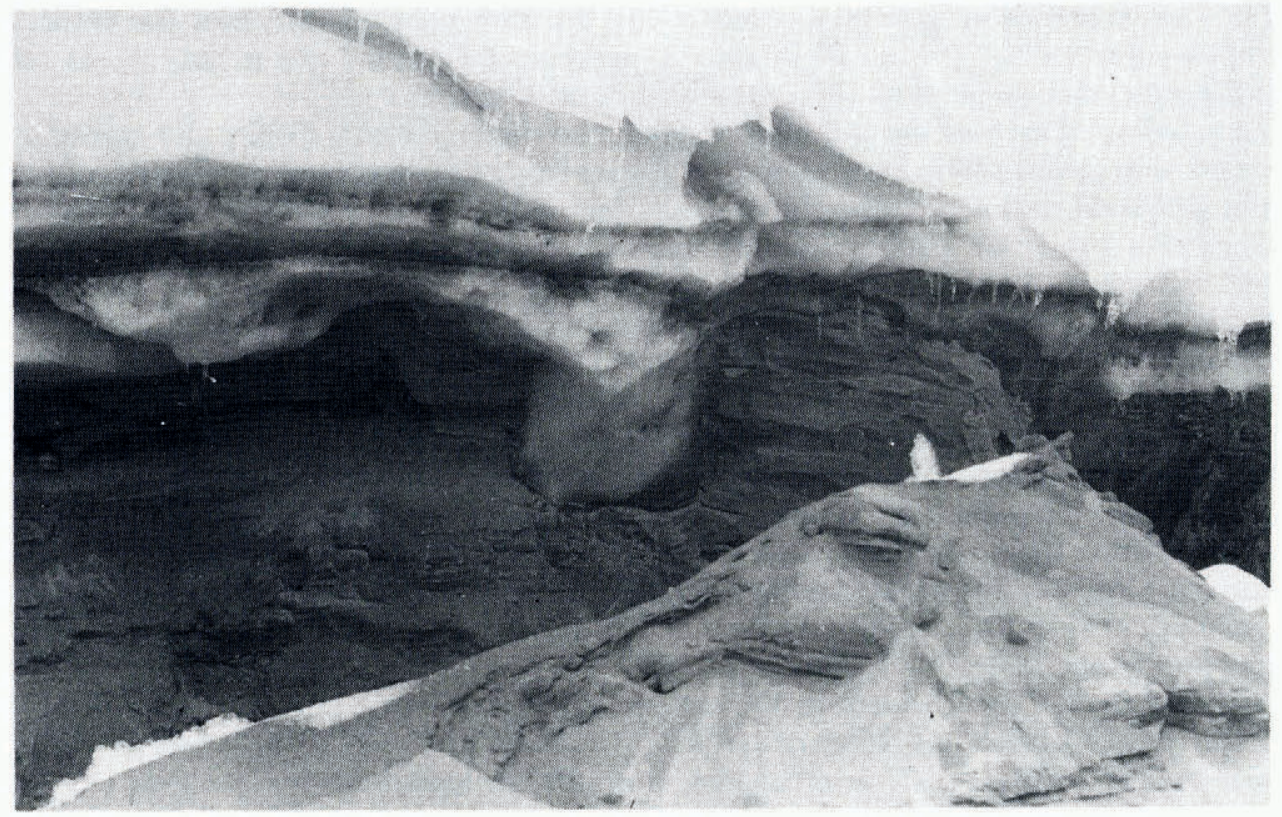

(b)

Fig. 9. Deformed masses of aeolian sand beneath Wright Lower Glacier, Wright Valley, Victoria Land, Antarctica.

(a) Detached and rotated blocks lie within the basal ice. The substratum is fractured, with voids and intrusions of glacier ice within it.

(b) Presumed original location of a block that has now been detached and transported away (plucked). Sandy laminae within the ice are derived from the bed. 
joint planes and into voids as diapiric masses. Disturbance of rippled beds and cross stratification indicate that flow of frozen sand has also occurred, although the style of folding is difficult to reconstruct.

Masses of frozen sand have been incorporated within the glacier and occur up to $2 \mathrm{~m}$ above the bed. These may be cuboidal masses which are probably joint-bounded blocks plucked from the substratum, or lenticular or sheet-like masses (Fig. 9). These latter may have been attenuated by deformation in the ice, or they may have been plucked from the bed in that form. No unequivocally original sedimentary structures were observed in them, which may be evidence that they have been attenuated by flow.

There are also numerous disaggregated sand grains in the ice which are clearly derived from the bed. These may represent individual grains incorporated by the same process as the larger aggregated masses, or the latter's sheared-out remnants.

There are three important conclusions to be drawn at this site:

(1) The frozen sediment bed has deformed both by fracture and flow.

(2) Masses of sediment have been plucked from the bed without disaggregation.

(3) The flow process has taken the sediment masses several metres above the bed, and the underlying ice does not represent regelation ice or ice formed from subglacial water.

\section{Discussion}

I suggest that the apparent ease of plucking at this site reflects two things: first, the adhesive bond between the glacier and frozen-bed sediments, which are thus subjected to a high tractive force that is probably enhanced by the much greater small-scale roughness of a bed composed of spheroidal grains compared with smooth bedrock (Boulton, [ ${ }^{\mathrm{c}}{ }_{1975]) \text {; and }}$ secondly, the relatively smaller cohesive strength of ice-cemented sand compared to most rock masses. The existence of ice strata, zones of low ice saturation of intergranular voids, and large open voids will all tend to facilitate this process. I suggest that the large voids reflect major differential movement of adjacent joint-bounded masses.

The problem of incorporating masses of subglacial material into a glacier and transporting them more than a few centimetres above the glacier bed was recognized by Weertman ( $196 \mathbf{r}$ ) when he proposed that net freezing-on of subglacial melt water to the glacier sole in the outer cold zone of a sub-polar glacier could produce thick englacial debris sequences. However, this will not suffice at the snout of Wright Lower Glacier as there is no free water. The temperature at the base of the ice cliff, measured in a $6 \mathrm{~m}$ probe, was $-15.4^{\circ} \mathrm{C}$.

The difficulty of appealing to shear planes as agents of incorporation is that, for twodimensional flow, the down-glacier ice must be stationary whilst the sediment layer is incorporated, which would require very strange patterns of movement to incorporate a multilayered debris sequence. However, this difficulty disappears if we consider flow over a realistic three-dimensional bed. When a glacier flows over a hummock, which is not elongated transverse to flow, the ice moving round the flanks of the hummock often flows into the lee-side position more rapidly than that moving over the summit. Thus, sediment masses torn from the summit or transported over the summit of a hummock may rise above the glacier bed by flow of flanking ice beneath it.

The basal freezing mechanism of Weertman (I96I) has been widely used and developed (Boulton, 1972; Clayton and Moran, [ ${ }^{\mathrm{c}}$ 1974]; Sugden, 1974), but as yet there is no direct evidence that it occurs. There is no reason to doubt the hypothesis but perhaps we should review the many geological situations in which it has been used as an explanation to inquire if in some cases the process described here could be responsible.

The existence of a frozen substratum of unlithified sediment does not necessarily inhibit large-scale subglacial deformation. If the unlithified substratum is thick and only its upper part is frozen, precisely the same rapid deformation may occur beneath the frozen/unfrozen sediment interface, as occurs immediately beneath the glacier sole at Breiðamerkurjökull. 


\section{Synthesis}

(I) I suggest that there are two principal styles of erosion: (a) where the substratum is relatively resistant compared with glacier ice and is composed of cohesive material; (b) where the substratum is relatively deformable compared with glacier ice and is of low or zero adhesion. In (a), fragments of that substratum are eroded by inclusion and transported within the glacier. Long-distance transport is possible. In (b), it is eroded primarily as a result of deformation beneath the glacier. Long-distance transport is unlikely. Style (a) is typical of bedrock surfaces beneath temperate or cold glacier ice. Style (b) is typical of unlithified sediment beneath temperate ice. Unlithified frozen sediment beneath cold ice shares characteristics of both styles. It may suffer from block inclusion in the glacier as in style (a) and subglacial deformation as in style (b).

(2) The absence of significant incorporation of subglacial material when this is composed of unfrozen unlithified sediments is testified to by those areas where tills derived from fringing bedrock overlie extensive beds of sandy material without showing signs of incorporation. This is a considerable contrast to the way in which tills reflect changing bedrock lithologies.

Unlithified sediments, which are incorporated in tills on a large scale, tend to occur as coherent blocks or "floes" in which original internal structures can still be discerned (Ruszczyńska-Szenajch, I 973). I suggest that this reflects erosion of a frozen substratum.

(3) Stratified unlithified sediments which have been deformed beneath an active glacier show a characteristic style of folding, in which isoclinal synclines with low-angle axial planes close up-glacier. Such folding can be readily identified over broad areas over-ridden by ice sheets and glaciers during the Pleistocene. Drumlins may also largely reflect subglacial deformation.

It is argued (Boulton and Jones, 1979) that a stratum of sediment undergoing deformation beneath a glacier will affect the glacier's stability and may lead to a substantially lower profile than for a glacier resting on bedrock. Existence of characteristic subglacial fold styles and drumlins may be evidence of this.

Glaciers resting on fine-grained sediment may be prone to considerable instability and surging behaviour. Changes in subglacial water discharge, or mass balance, or the position of the glacier snout may cause the sediment bed to deform, or an already deforming bed to deform more rapidly, possibly at surging velocities.

(4) Modern glaciers are probably largely underlain by rigid bedrock. They erode bedrock by incorporation of bedrock fragments and produce a lineated rock substratum. The glacier sole forms the dynamic base of the glacier.

From time to time during the Quaternary, glaciers have expanded far beyond those core areas and have flowed over extensive fringing areas of soft sediment. This material has been primarily eroded by subglacial deformation, which has also led to complementary depositional activity and to a lineated drumlinized landscape. Transport distances have been small and the dynamic base of the glacier system may have been well beneath the apparent glacier sole.

(5) It is suggested that great longitudinal extent of major lineated features, be they grooves or ridges, is facilitated by a homogeneous substratum of rock or unlithified sediment and by the maintenance of steady subglacial conditions for long periods.

\section{Acknowledgements}

I am very grateful for field assistance to many University of East Anglia students and Icelandic friends, in particular to Flosi and Sigidur Bjørnsson of Kvisker. Dr E. M. Morris helped design measuring systems, Dr A. Armstrong assisted in the reduction of field data, and F. Robinson performed many valuable workshop tasks. Preliminary work by P. Robinson 
helped improve the design of the subglacial deformation experiment. The work was generously supported by the Royal Society and the Natural Environment Research Council (Grant $\left.\mathrm{GR}_{3} / 3226\right)$.

\section{REFERENCES}

Aario, R. 1977. Classification and terminology of morainic landforms in Finland. Boreas, Vol. 6, No. 2, p. 87-100. Barsch, D. I971. Rock glaciers and ice-cored moraines. Geografiska Annaler, Vol. 53A, Nos. 3-4, p. $203^{-06}$.

Boulton, G. S. 1972. The role of thermal régime in glacial sedimentation. (In Price, R. J., and Sugden, D. E., comp. Polar geomorphology. London, Institute of British Geographers, p. I-I 9. (Institute of British Geographers. Special Publication No. 4.))

Boulton, G. S. [ ${ }^{\mathrm{c}}{ }_{1}$ 974.] Processes and pattern of glacial erosion. (In Coates, D. R., ed. Glacial geomorphology. Binghamton, N.Y., State University of New York, p. 41-87. (Publications in Geomorphology.))

Boulton, G. S. [ ${ }^{\mathrm{c}} \mathrm{I}$ 975.] Processes and patterns of subglacial sedimentation: a theoretical approach. (In Wright, A. E., and Moseley, F., ed. Ice ages ancient and modern. Liverpool, Seel House Press, p. 7-42.)

Boulton, G. S. 1978. Boulder shapes and grain size distribution of debris as indicators of transport paths through a glacier and till genesis. Sedimentology, Vol. 25, No. 6, p. 773-99.

Boulton, G. S., and Jones, A. S. 1979. Stability of temperate ice caps and ice sheets resting on beds of deformable sediment. Fournal of Glaciology, Vol. 24, No. 90.

Boulton, G. S., and Paul, M. A. 1976. The influence of genetic processes on some geotechnical properties of glacial tills. Quarterly fournal of Engineering Geology, Vol. 9, No. 3, p. 159-94.

Boulton, G. S., and Vivian, R. A. 1973. Underneath the glaciers. Geographical Magazine, Vol. 45, No. 4, p. 31 1-16.

Boulton, G. S., and others. I974. Subglacial shearing and crushing, and the role of water pressures in tills from south-east Iceland, by G. S. Boulton, D. L. Dent, and E. M. Morris. Geografiska Annaler, Vol. 56A, Nos. 3-4, p. 135-45.

Boulton, G. S., and others. 1979. Direct measurement of stress at the base of a glacier, by G. S. Boulton, E. M. Morris, A. A. Armstrong, and A. Thomas. Journal of Glaciology, Vol. 22, No. 86, p. 3-24.

Bowden, F. P., and Tabor, D. 1950. The friction and lubrication of solids. Part I. Oxford, Clarendon Press. (International Series of Monographs on Physics.)

Carol, H. 1947. The formation of roches moutonnées. Fournal of Glaciology, Vol. 1, No. 2, p. 57-59.

Clayton, L., and Moran, S. R. [ [ ${ }^{\mathrm{I}}$ 974.] A glacial process-form model. (In Coates, D. R., ed. Glacial geomorphology. Binghamton, N.Y., State University of New York, p. 89-119. (Publications in Geomorphology.))

Engelder, J. T., and Scholz, C. H. 1976. The role of asperity indentation and ploughing in rock friction-2. Influence of relative hardness and normal load. International Journal of Rock Mechanics and Mining Sciences, Vol. ${ }_{13}$, No. 5 , p. $155^{-6} 3$.

Galibert, M. G. 1962. Recherches sur les processus d'érosion glaciaires de la haute montagne alpine. Bulletin de l'Association Géographique Français, Vol. 304, No. 4, p. 8-46.

Goldthwait, R. P. I 960 . Study of ice cliff in Nunatarssuaq, Greenland. U.S. Snow, Ice and Permafrost Research Establishment. Technical Report 39.

Holdsworth, G. I 974 . Meserve Glacier, Wright Valley, Antarctica: part I. Basal processes. Ohio State University.

Institute of Polar Studies. Report No. 37.
Jelgersma, S., and Breeuwer, J. B. 1975. Toelichting bij de kaart glaciale verschijnselen gedurende het Saalien, I : 6oo.ooo. (In Zagwijn, W. H., and Staalduinen, C. J. van, ed. Toelichting bij geologische overzichtskaarten van Nederland. Haarlem, Rijks Geologische Dienst, p. 93-102.)

Jellinek, H. H. G. I 959 . Adhesive properties of ice. Fournal of Colloid Science, Vol. 14, No. 3, p. $268-80$.

Lewis, W. V. 1940. The function of meltwater in cirque formation. Geographical Review, Vol. 30, No. I, p. 64-83.

Lewis, W. V. I 947 . The formation of roches moutonnées - some comments on Dr Carol's article. Fournal of Glaciology, Vol. I, No. 2, p. 6o-63.

Matthes, F. E. 1930. Geological history of the Yosemite valley. U.S. Geological Survey. Professional Paper 160.

Mokievsky-Zubok, O. 1978. A slide of glacier ice and rocks in western Canada. Journal of Glaciology, Vol. 20, No. 82 , p. $215^{-1} 7$.

Nobles, L. H., and Weertman, J. [ [ ${ }^{\mathrm{c}} \mathrm{I} 97 \mathrm{I}$.] Influence of irregularities of the bed of an ice sheet on deposition rate of till. (In Goldthwait, R. P., ed. Till: a symposium. [Columbus], Ohio, Ohio State University Press, p. 11 7-26.)

Nye, J. F. 1970. Glacier sliding without cavitation in a linear viscous approximation. Proceedings of the Royal Society of London, Ser. A, Vol. 315 , No. 1522, p. $381-403$.

Nye, J. F., and Martin, P. C. S. 1968. Glacial erosion. Union de Géodésie et Géophysique Internationale. Association Internationale d'Hydrologie Scientifique. Assemblée générale de Berne, 25 sept. 7 oct. 1967. [Commission de Neiges et Glaces.] Rapports et discussions, p. 78-86. (Publication No. 79 de l'Association Internationale d'Hydrologie Scientifique.)

Peterson, D. N. 1970. Glaciological investigations on the Casement Glacier, southeast Alaska. Ohio State University. Institute of Polar Studies. Report No. 36.

Roscoe, R. I 952 . The viscosity of suspensions of rigid spheres. British Fournal of Applied Physics, Vol. 3, [No. 8], p. $267-69$.

Ruszczyńska-Szenajch, H. 1973. Kry lodowcowe wyciśnięte glacitektonicznie na terenie SE Mazowsza i S Podlasia [Glacial floes squeezed by ice sheets in mid-eastern Poland]. Kwartalnik Geologiczny, Tom 1 7, Nr. 3, p. $560-76$. 
Scholz, C. H., and Engelder, J. T. 1976. The role of asperity indentation and ploughing in rock friction-1. Asperity creep and stick-slip. International Journal of Rock Mechanics and Mining Sciences, Vol. I 3, No. 5, p. 149-54.

Shaw, J. 1975. The formation of glacial flutings. Royal Society of New Zealand. Bulletin 1 3, p. 253-58.

Shaw, J., and Freschauf, R. C. 1973. A kinematic discussion of the formation of glacial flutings. Canadian Geographer, Vol. 17, No. I, p. 19-35.

Smalley, I. J., and Unwin, D. J. I968. The formation and shape of drumlins and their distribution and orientation in drumlin fields. Journal of Glaciology, Vol, 7, No. 51, p. 377-9o.

Sugden, D. E. 1974. Landscapes of glacial erosion in Greenland and their relationship to ice, topographic and bedrock conditions. (In Waters, R. S., and Brown, E. H., ed. Progress in geomorphology. London, Institute of British Geographers, p. $177-95$. (Institute of British Geographers. Special Publication No. 7.))

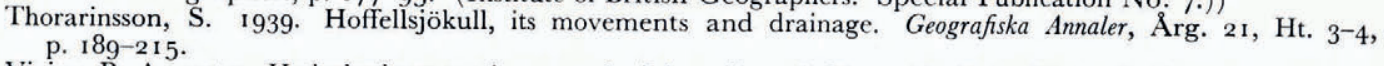

Vivian, R. A. 1970. Hydrologie et erosion sous-glaciaire. Revue de Géographie Alpine, Tom. 58, Fasc. 2, p. 24 I-64.

Vivian, R. A. 1975. Les glaciers des Alpes occidentales. Grenoble, Imprimerie Allier.

Weertman, J. 1957. On the sliding of glaciers. Fournal of Glaciology, Vol. 3, No. 21, p. 33-38.

Weertman, J. I961. Mechanisms for the formation of inner moraines found near the edge of cold ice caps and ice sheets. Journal of Glaciology, Vol. 3 , No. 30, p. 965-78.

Weertman, J. 1972. General theory of water flow at the base of a glacier or ice sheet. Reviews of Geophysics and Space Physics, Vol. 10, No. 1, p. 287-333.

Ziegler, T., and Olsen, H. C. I973. Materialtransportundersökelser i norske bre-elver 1971. Norges Vassdrags- og Elektrisetetsvesen. Vassdragsdirektoratet. Hydrologisk Avdeling. Rapport, Nr. 4.

\section{DISGUSSION}

W. B. КАмв : In relation to your concept of lateral streaming of basal debris into grooves, one can understand readily how the thickness of the basal debris would be increased over the grooves by lateral diversion of debris from over bedrock highs, but what physical process could produce an increase in the volume concentration of debris there, which you appeal to in your theory of groove formation and which you seem to have observed in a tunnel in Iceland?

G. S. Boulton: In the thin basal debris-bearing horizons, which I have studied in Icelandic glaciers and in the Alps, the concentration of debris increases upwards from the glacier sole. I suggest that, as ice is deflected around the lateral flanks of a bedrock bump, the lowest part is deflected first and that subsequently higher and higher horizons are deflected laterally. Thus the debris-rich basal ice in inter-bump troughs tends to be preferentially enriched in the ice which previously lay immediately above the glacier sole.

A second possible mechanism is the squeezing out of melt water from basal debris-rich ice. Melting and drainage could be enhanced by the numerous stress concentrations at interparticle contacts and the frequent cavities in debris-rich basal ice.

A. Dreimanis: You propose that the main deposition of till in resistant bedrock areas is on the up-glacier part of bedrock knobs. How can you then explain the dominance of till deposition on the lee side of bedrock knobs, common in the Lake Huron-Georgian Bay Precambrian shield area, and also on the lee side of drumlins. Is this not a transitional stage to the softsediment deformation?

Boulton: I suggest that the distribution of till beneath glaciers is governed by primary depositional processes and by subsequent post-depositional deformation which redistributes it. I suggest that primary deposition often occurs preferentially on the up-glacier side of obstacles but that, if pre-existing till or other sediments become mobile beneath the glacier, they often accumulate as "tails" in the stress-shadow zone on the lee sides of obstacles.

Dreimanis: You have demonstrated clearly how a rod was broken and its fragments moved down-glacier in till to a depth of $0.6 \mathrm{~m}$. MacClintock and I (MacClintock and Dreimanis, 1964) observed similar down-glacier displacement along spoon-shaped shear planes, reorientation of alignment of pebbles and even new striations on bedrock to a depth of several metres, but only in a wide groove between two drumlins in a St Lawrence Seaway excavation; none of these secondary features was present in the drumlins flanking the groove. What mechanism would be responsible for these deformations and re-orientations? 
Boulton: The rates of deformation that I have observed subglacially are greatest in the troughs between ridges which are the subglacial continuations of drumlins. Flow lines appear to converge towards the axis of the trough. I have explained this as evidence of slow deformation of till in the drumlin form and deflection of deforming till towards the trough. I see no reason why a similar mechanism should not produce erosion of otherwise stable drumlin material, and its displacement as a deforming layer along the trough, as in the case cited by Professor Dreimanis.

J. Weertman: You are to be congratulated for your work on deformable beds. It is a new, major field of research.

It is not clear to me what is your term $\mathcal{N}$ for effective pressure of a rock against the bed. If a rock were resting, say, at the bottom of a lake the effective force pushing it against the bottom is its weight less the buoyancy force of the water, and not the force from the weight of the column of water above it. The ice surrounding a rock at the glacier bed should also act like a liquid. The effective pressure $\mathcal{N}$ that you use could be considerably smaller than the overburden ice pressure.

Boulton: I do not suggest that the effective pressure $N$ at the glacier bed is equal to the overburden pressure and agree that it could be considerably less. I suggest that the effective pressure is likely to be governed by the percentage of the bed area in which "real" contact is made between clasts held in the ice and the bed. If the clast concentration in the glacier sole is small, $\mathcal{N}$ will be small but, if the concentration is high, $\mathcal{N}$ will be large.

\section{REFERENCE}

MacClintock, P., and Dreimanis, A. 1964. Reorientation of till fabric by overriding glacier in the St Lawrence valley. American Journal of Science, Vol. 262, No. 1, p. 133-42. 